University of Louisville

ThinkIR: The University of Louisville's Institutional Repository

Electronic Theses and Dissertations

$1-1929$

\title{
Truancy in the public schools : its cause and cure.
}

Kathleen Miller

University of Louisville

Follow this and additional works at: https://ir.library.louisville.edu/etd

Part of the Biology Commons, and the Education Commons

\section{Recommended Citation}

Miller, Kathleen, "Truancy in the public schools : its cause and cure." (1929). Electronic Theses and Dissertations. Paper 981.

https://doi.org/10.18297/etd/981

This Master's Thesis is brought to you for free and open access by ThinkIR: The University of Louisville's Institutional Repository. It has been accepted for inclusion in Electronic Theses and Dissertations by an authorized administrator of ThinkIR: The University of Louisville's Institutional Repository. This title appears here courtesy of the author, who has retained all other copyrights. For more information, please contact thinkir@louisville.edu. 
UNIVERSITY OF LOUISVILLE

"TRUANCY IN THE PUBLIC SCHOOLS: ITS GAUSE AND CURE"

\author{
A Dissertation \\ Submitted to the Faculty \\ Of The Graduate School of The College of Liberal Arts \\ In Partial Fulfillment of the \\ Requirements for the Degree \\ of Master of Arts
}

Department of Biology

By

KATHLEEN MILLER

1929 
In this age in which we live it is not hard to find a problem but it is often difficult to choose one. These problems have arisen as a result of the complex social and industrial institutions which have evolved as a result of human inventiveness and the competition among men to better our living eonditions and increase our comforts. According to statistics compiled by the General Federation of Women's Clubs, the proportion of those who enjoy these modern conveniences is small when compared to those who have suffered as a result.

The problem of this study is one which is in the process of being solved. Ii most evils, it was discovered only after it had invaded the lives of children and robbed them of their real educational opportunity. Bureaus, attendance departments and commissions have been created to study the problem and prevent its growth. It was hoped that eventually a satisfactory solution would be offered which would in a large way alleviate the proposition. Great strides have been made and many of the underlying causes have been discovered, yet there is much to learn that will be brought to light with the effort that is being exerted by these offices.

The cure for the problem will be the climax of the work. Many suggestions have been offered, a few adopted, but none with a satisfactory result. Undoubtedly the cure for the problem is not far off and when it is discovered the application will be but a matter of routine. 


\section{INDEX}

Study of Philadelphia, Pennsylvania ........................ 1

Study of St. Louis, Missouri $\ldots \ldots \ldots \ldots \ldots \ldots \ldots \ldots \ldots \ldots$............... 5

Study of Indianapolis, Indiana $\ldots \ldots \ldots \ldots \ldots \ldots \ldots \ldots \ldots$. Page 7

Study of Springfield, Massachusetts .......................... 10

Study of Rochester, New York $\ldots \ldots \ldots \ldots \ldots \ldots \ldots \ldots \ldots \ldots$ Page 16

Study of Detroit, Michigan $\ldots \ldots \ldots \ldots \ldots \ldots \ldots \ldots \ldots \ldots$................... 23

Study of Boston, Massachusetts $\ldots \ldots \ldots \ldots \ldots \ldots \ldots \ldots \ldots$.................... 28

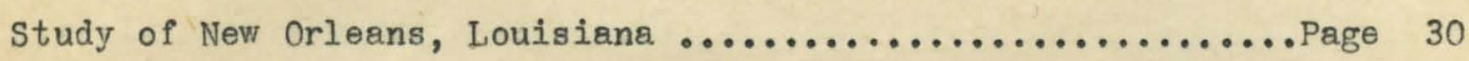

Study of Portland, Oregon $\ldots \ldots \ldots \ldots \ldots \ldots \ldots \ldots \ldots \ldots$ Page 32

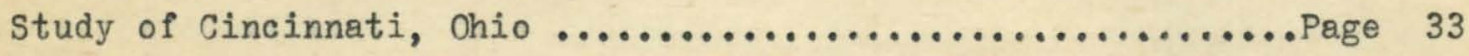

Study of Harrisburg, Pennsylvania ........................... 34

Study of Chicago, Illinois $\ldots \ldots \ldots \ldots \ldots \ldots \ldots \ldots \ldots \ldots$. Page 36

study of Cleveland, ohio .................................... 45

Bibliography 
TRUANCY IN THE PUBLIC SGHOOLS: ITS CAUSE AND GURE

"Children whose school progress is erratic and puzzling, whose behavior is perplexing or whose personalities manifest traits that give cause for concern are to be found in every school."

A study of non-attendance and its causes is therefore a matter of paramount importance. The time that the majority of children spend in the grades is too valuable to be lost and if they, do not obtain from school, through a regular daily attendance, an interest in the continuation of self-development, their educational loss is likely to have its further effect in a deterioration of character.

The effect of non-attendance can only be ascertained by carefully compiled statistics of absences. But in Louisville, as in other cities, published school reports do not contain such statistics. "Average daily attendance" throws no light on this problem. What is needed is a series of tables showing the number of children who have been absent different periods of time, varying from a day to a week or more, and the cause of their absence. Since tables of this nature are not available a careful study was undertaken of the attendance departments of thirteen of the larger cities in the hope that the statistics obtained might throw light on the whole problem of school attendance.

The material used in the presnt study consists largely of annuel reports compiled by the attendance departments of the cities represented, a review of each of which follows.

In the records of the attendance department of the city of Philadelphia, 
Pennsylvania, compiled by Henry J. Gideon, unexcused absences are classified under three headings, parental neglect, illegal employment and truancy. The records show that parental neglect is responsible for more than two-thirds of the unexcused absences, truancy slightly less than one-third and illegal employment one-twentieth of all unexcused absences. Among children of compulsory and non-compulsory age there is a larger proportion of unexcused absences in the junior high schools than in the senior high schools. And there is the same proportion of unexcused absences in the elementary schools as in the senior high schools, exclusive of special classes in the elementary schools.

Personal illness of the child is the largest single item among the causes of excused absences. The maintenance of good health is therefore an important factor to be considered in improving the school attendance of children. The control of contagious diseases and quarantine ordinances have helped to improve the attendance of school children, especially in the lower grades.

The following tables of absences gives us a more general view of the relative postions of the schools:

A

PUPILS OF COMPULSORY AND NON-CONPULSORY AGT

\section{Type of school}

Kindergartens

Special schools and classes

Elementary schools, grades 1-8

Junior high

Senior high

Total

Continuation
Rate of absence

$20.3 \%$

$17.2 \%$

$10.2 \%$

$9.6 \%$

$9.2 \%$

$10.7 \%$

$8.7 \%$
Excused Unexcused

$86 \%$. $14 \%$

$68 \% \quad 32 \%$

$89 \% \quad 11 \%$

$84 \% \quad 16 \%$

$89 \% \quad 11 \%$

$87 \% \quad 13 \%$

$59 \% \quad 41 \%$

During the year 119,110 children were found to be absent without a legal excuse by the attendance department. 142,049 were absent with excuses and 81,564 were dismissals. Illness of the child or illness in the family was 
found to be responsible for 106,860 cases of excused absence. Investigation of absence found to be unexcused disclosed 89,322 cases due to parental neglect, 28,755 to truancy and 1,033 to illegal employment. In addition to cases reported by schools 17.618 special investigations were made as the result of letters and telephone calls to the central office and their branches. The rate of absence due to truancy was reduced in the public schools from twenty-seven percent to twenty-six percent in the regular classes and from fifty-eight percent to forty-one percent in the continuation classes. The records of this year and of the preceding six years show several recurrent features. (1) Truant boys outnumber truant girls at the ratio of eight to one. (2) Truants appear in the first grade, (even in the kindergarten) and gradually increase in number to the fifth grade where the peak is reached, the number gradually shading off through the higher elementary grades and through the high schools. (3) More than half of the truant group are boys fourteen and fifteen years of age. Fifty-three percent of these boys are in grades below the seventh. Truancy, therefore, is particularly the problem of the adolescent boy who is seriously retarded in school. The causes of delinquency among children are many and varied but truancy is due (1) to the carelessness or ignorance of parents and to vicious or inadequate home training, (2) to the evil influence of idle lazy companions, most of whom are over sixteen years of age, (3) to a strong aversion to school due to failure in studies and constant retardation and (4) to personality difficulties and inability to make social adjustments with teachers and pupils.

The records of 1928 show that children of foreign born parents furnished aproximately fifty-four percent of the truants of the city. Much truancy is unquestionably due to the inability of foreign born, non-English speaking par- 
ents to guide and control their children, the latter being able to speak English. The dependence of parents upon thier children to interpret English for them sometimes weakens their respect for them and breaks down morale and discipline in the home.

It is evident that parental neglect causes as much unexcused absence among girls as boys, but truancy of boys is responsible for more than six times as much unexcused absence as truancy among girls. There is also more unexcused absence among boys due to illegal employment than among girls.

Much truancy is a concommitant of retardation. The pupil failing in school tends to play truant. The question is often asked are truants retarded because of absence or absent beçause of retardation and the maladjustment that it brings? The tables show that in the first eight grades sixty-four percent of the truants were one or more years retarded and seventeen and six-tenths percent of all truants were special class students, many of whom were seriously retarded.

Negroes constitute eight percent of the total school population, but they contribute fifteen percent of the truants of the city. Home conditions especially poor housing conditions and the employed mother's absence from the home during the day, are responsible for much of the truancy among colored children. Retardation is also a contributing factor.

Physically and mentally handicapped children are provided for in special classes. All children are given thorough physical and psychological tests and those who do not attain a fixed degree of efficiency are placed in classes designed for this specific purpose. The following table shows the types of physical disabilities reported for examination to the division of school medical 
inspection:

\begin{tabular}{|c|c|c|c|c|c|c|c|c|c|c|c|}
\hline$r$ & Blind & $\begin{array}{l}\text { Crip- } \\
\text { pled }\end{array}$ & Deaf & $\begin{array}{l}\text { Speech } \\
\text { Defect }\end{array}$ & $\begin{array}{l}\text { Epi- } \\
\text { leptic }\end{array}$ & $\begin{array}{l}\text { Back- } \\
\text { ward }\end{array}$ & $\begin{array}{l}\text { Tuber- } \\
\text { culous }\end{array}$ & $\begin{array}{l}\text { Heart } \\
\text { Trouble }\end{array}$ & $\begin{array}{l}\text { Ner- } \\
\text { vous }\end{array}$ & Others & Totel \\
\hline & 4 & 22 & 4 & 7 & 30 & 299 & 6 & 4 & ר & 138 & \\
\hline & 3 & 28 & 4 & 4 & 27 & 364 & 17 & 2 & 8 & 122 & 579 \\
\hline
\end{tabular}

According to Mr. John B. Quinn, chief attendance officer of St. Louis, Missouri, the school authorities look upon truancy as essentially a school problem to be handled within the school system itself. Truancy is sometimes due to a condition classified as "neglected" by the juvenile court. In fortyfour percent of 731 truancy cases, dealt with in 1920-1921, one or both parents were dead, separated or divorced. Sixty-six percent of the 119 cases of juvenile delinquency dealt with by the division the homes were found to be broken.

A classification of cases reported for investigation follows:

A. Lawful Excuses:

1. Absence due to illness, quarantine, poverty etc............29,893

2. Cases of children of extra-legal age investigated.......... 3,966

3. Cases not found at addresses given (also removals from city) $, 5,762$ Total

B. Unlawful Excuses:

1. Cases of irregular attendance investigated...............28,175

2. Cases of non-attendance investigated..................... 2,130

3. Disorderly juvenile offenders investigated................ 930

4. Cases of truancy investigated........................ 2,303

5. Gases found illegally employed...................... 120 Total

Total number of cases reported for investigation

(The above figures included repeaters) 73,279

The next tables gives a comprehensive survey of the conditions contriuting to truancy. The age, race, birth, status of parents and environment are analyzed in one of the best charts found in the field. 


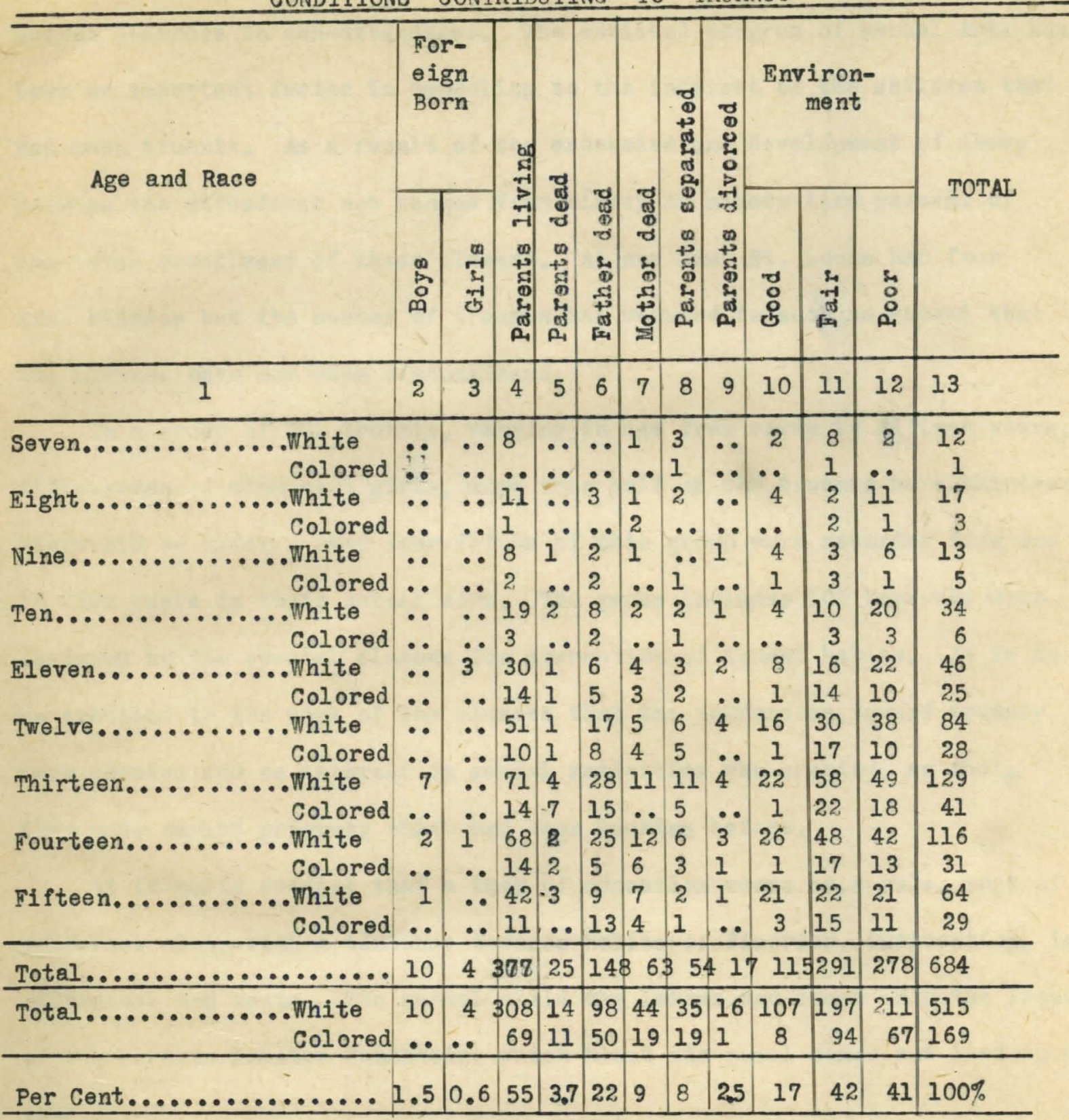


The establishment of boy's day classes for truants has resulted in a marked decrease in non-attendance. The enriched program of Manual Arts has been an important factor in appealing to the interest of the children that had been truants. As a result of the expansion and development of these courses the attendance now ranges from ninety to ninety-five percent of the total enrollment of these classes. At one time St. Louis had four such classes but the number of truants has reduced to such an extent that the classes have now been discontinued.

In a study of 731 truants, ranging in age from seven to fifteen years, fifty-seven of whom were girls, more than half of the truants were thirteen years old or older. Over four-fifths of this group were retarded from one to five years in their school work. The group includes 109 boys who were assigned to the special classes for correction of truant habits. It is to be credited to the work of the classes that the tendencies toward truancy were checked and an interest in school activities was created, so that 0 they made marked progress which had been lacking before.

It is quite evident that a lack of education means as a rule, lack of self-restraint, with a tendency towards habits of disorder, inattention, indifference and waste. The school child who learns and knows only the lessons of the streets imbibes tendencies which blunt his moral sense and lead to depravity.

In the records of the attendance department of the city of Indianapolis, Indiana, compiled by Miss Blanche Merry, is found the following.

"It is my contention that the attendance officers should approach every problem of non-attendance on the basis of learning the cause and whatever it 
may be, he should proceed to remove it. If it proves to be poverty then he should seek the trustees or other welfare agencies; if it should be ill health, then he should seek a means or an agency to restore the health of the child; if it should happen to be a matter of distance, he should cooperate with the home and attempt to arrange for proper transportation; if family disention is the cause, he should seek some way of ironing out the difficulties in order that the child make take the best advantage of the opportunities offered. The last class of cases is very often the case and when a mother is down-hearted or discouraged she is not able to play the game for the best welfare of her child." Probably one of the best points made by Miss Merry is that the attendance officer should seek to solve the problem through personal contact, rather than take the case to court, except of course, in that class of cases which absolutely require judicial action.

All school officials should count every day of absence in making a record of a student's attendance. If a child is absent for illness or a temporary permit, then the absence is legal. On the other hand if a child is absent for causes other than those above, the absence would be illegal. Tardiness is also considered as absence and is either legal or illegal.

In some rural districts there are children out of school because there is no transportation furnished to the schools and in some cases there are not any schools. Others may have married, and if so, cannot be compelled to attend school. If there are any other causes, legal or illegal, which keep a child from school they should be listed with the number falling under their head. There are certain specific cases where children of compulsary attendance age do not attend school. For example there are those children who must 
support themselves or their families, or even both. These cases are taken care of and released from school on a special work certificate. Other examples are those children who are feeble minded or physically unfit. These classes are excused from school attendence by the superintendent. The lav provides for these cases in the following manner:

SPECIAL SCHOOLS:

- a. Children who are deaf or blind or even partially so shall be sent to the Indiana state school for such.

b. Children who are mentally unfit may be sent to the school for feeble-minded youths.

c. Children who are delinquent or incorrigible may be sent to the Boy's or Girl's Industrial school as the case may be.

d. Habitual absentees may be brought before the juvenile court or even the circuit or superior court on the recommendation of either the attendance officer or the superintendent, and mey be declared a confirmed truant and confined to the parental school or placed under the care of a probation officer.

e. Those who are physically disabled are taken care of in special classes.

f. Opportunity classes are offered for slow and backward children.

There is, prevailing at this time, a general belief that all children who appear to be slow mentally or subnormal, should be permitted to drop out of school at the age of fourteen and seek employment. This is a heathenish doctrine and has no place in our system of societty. Common decency should seem to indicate that the weak should not be discriminated against because of their weakness. Indiana is handling this problem in a sane and just way. The table on the following page demonstrates to what extent and the effect the Indiana program is aiding school attendance. 
CH ILDREN IN SCHOOL

COUNTY

CITY

TOTAL

Enrollments: (Including all pupils attending school)

Public Schools
Parochial Schools
Private Schools

Totel
324,120

10,244

490

334,854
249,720

47,973

2,163

299,856
573,840

58,217

2,653

634,710

CHILDREN OUT OF SCHOOL

Non-enrollments: ( 7 to 16 years only)

Employment certificates (14-16)

163

341

504

Feeble-minded:

At home

357

271

628

In institutions

162

197

359

Physically unfit:

At home

440

379

819

In institutions

88

125

213

Elementary Graduates out of school:

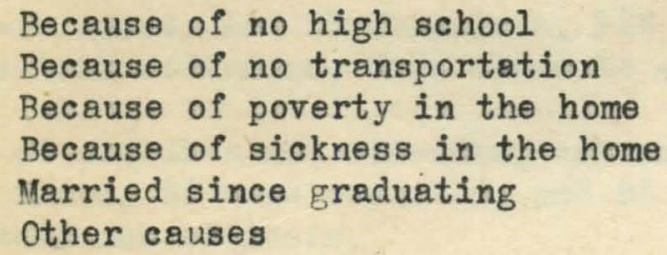

Total
460

220

77

70

56

78

2,171
460

220

126

103

100

111

3,643

Although the number of children not attending school is so small compared with the number attending (.0057 percent), the attendance department is still working hard so that some of the non-attendant group will be added to the attendant group.

The next report examined was that of the Springfield, Mass. attendance department which is in charge of Mr. James A. Parker. With reference to this report it is well to note that springfield is the smallest of the cities in the study and as a result the figures given will be proportionately smaller than those of the previous cities. 


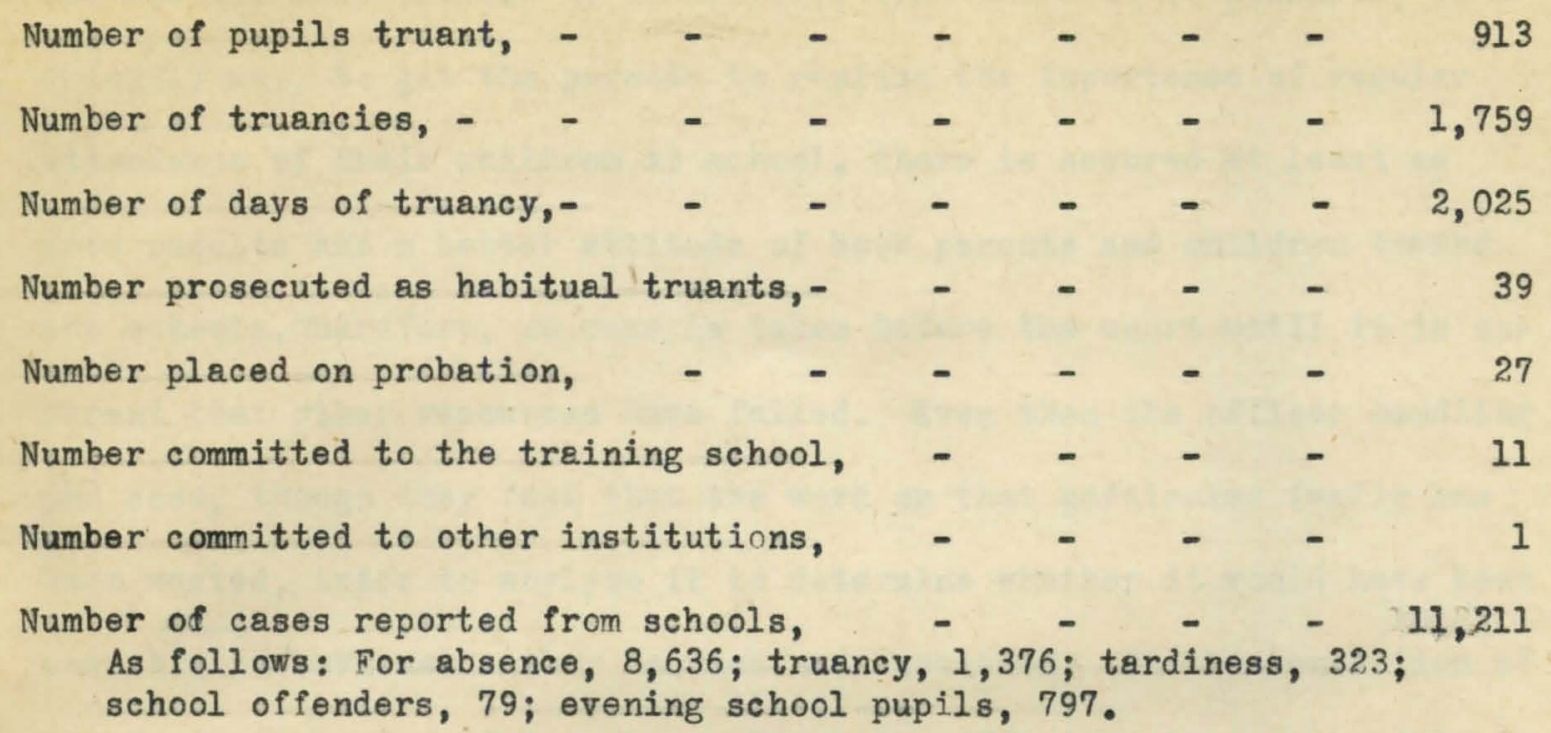

Number of children found about the streets, - _ - $\quad$ - 1,255

Upon investigation it was found that 993 were absentees; 195

were truants; 7 were school of fenders; 60 were non-attendants.

of the children found about the streets, 41 absentees, 31

truants, 1 school offender, 12 non-attendants were taken to

their homes; and 37 absentees, 123 truants, 3 non-attendants

2 school offenders, were taken to school.

Number of children not attending any school, -
of these, 59 were reported, and 88 were discovered by the

147

attendance officers.

These cases were disposed of as follows; 121 have entered school;

21 left town; 2 went to work; 3 were sick and physicians certifi-

cates were received.

As shown by the above statistics 7,127 children, more than one of every

four children of school age in the city, came in contact with the attendance

department at some time during the past year. That there were prosecuted before

the District Court only twenty-one parents for failure to cause their children

to attend school regularly indicates the extent to which co-operation rather

than force is the method used to secure regular attendance at school. This

method requires more visiting of the homes, more time for individual visits

and for interviewing of parents and children at the office and consequently

more people to do the work than would be required if every parent who violated 
the law was prosecuted. It is believed that where it is possible, in a friendly way, to get the parents to realize the importance of regular attendance of their children at school, there is secured at least as good results and a better attitude of both parents and children toward the schools. Therefore, no case is taken before the court until it is apparent that other resources have failed. Even then the officer handling the case, though they feel that the work on that particular family has been wasted, tries to anylyze it to determine whether it would have been possible to have used other tactics and succeeded. At the convention of the National League of Compulsory Education Officials it was brought out that one city about the size of Springfield prosecuted more than seven hundred parents in 1926 for failure to cause their children to attend school regularly.

Three hundred twenty-six boys were found to be selling papers who were under the legal age, but not one of them was prosecuted. Only two persons were prosecuted for the illegal employment of minors although two hundred thirty-nine were found illegally employed.

of the 7,127 children dealt with nine hundred thirteen were truants. Df thas number only thirty-nine were brought before the court. of these thirty-nine children only one boy was found to be in the average grade for his age. Two boys were in auxiliary classes. The other thirty-six were from one-half year to four and a half years below the normal grades, the average retardation being two and a half years. Only five of these boys had been examined in the psychological laboratory; apparently the teachers did not regard the retardation of the others as due to feeble-mindedness. Of the five boys examined, one, according to reports, was a moron, the other four were from one 
to two years retarded, in two cases the trouble was complicated by poor eyesight. These thirty-nine cases were responsible for one hundred ninety-itve truancies (about eleven percent of the total) and four hundred forty-four and one-half days of truancy (about twenty-two percent of the total). The effect of the home in the causation of truancy is shown in the following facts concerning these children: in six cases the father was dead; in one case the father was blind; in three cases the mother was dead; in one case the mother was in the state hospital for the insane; in one case there was a step-father and in another a step-mother; in fourteen cases the mothers worked; in one case the parents were separated, the boy living with the father in a rooming house; in one case the boy was living with a married sister who went out to work; in one case the father had been to court for non-support and there was constant friction in the home; in eight cases English was not the principal language spoken in the home. The age factor for this group is exceedingly interesting, only seven of the boys were below fourteen years of age, the age at which children may go to work. One of these was between eight and nine; three between ten and eleven, one between twelve and thirteen; and two between thirteen and fourteen. Of the other thirty-two, five boys and two girls were between fourteen and fifteen and twenty-three boys and two girls were between fifteen and sixteen. It is often considered an easy method of disposing of truants to advise them to do to work. In fact, this has sometimes been regarded as a panacea for truancy. That it is not, really a constructive method of meeting the problem appears from the figures for this group of truants who could not be cured of truancy without resort to the court.

The four girls had all been employed and had had sixteen jobs covering a total period of forty-six months, an average of four jobs each, with an : 
average duration of each job, including the periods of idleness before another was secured, of about three months. Fifteen of the boys had been employed at fifty-five jobs in a total period of one hundred and twenty-four months, an average of three and two-thirds jobs for each boy with an average duration for each job and the period of idleness preceding it, of about two and a quarter months. Another boy had been employed before coming to springfield and would not attend school here until taken before the court. Boys who have never been taught at home or in school to apply themselves to whatever is undertaken, find no pleasure in work and do not make good workers. When the legal compulsion, which requires either school attendance or legal employment, is withdrawn when these boys reach the age of sixteen years, they give up all pretense of work and become loafers as long as their parents will support them. There are several hundred of such boys between sixteen and nineteen years of age in Springfield, who, having had all the work they wanted, are living in idleness, a burden on their parents and society.

The continuous school census shows an increase over the preceding year of eight hundred thirty-eight children between five and sixteen years of age. It has been attempted, through co-operation with the schools and attendance officers, to stop all children found on the streets during school hours to secure data on all such children found between the ages of five and sixteen. of course this method of securing information is not entirely satisfactory. The last school census reported was taken nine years ago and since Springfield has undergone such tremendous changes it was deemed advisable to make a new enumeration, the results of which should be checked against the permanent census so as to show just how efficiently the present method has furnished information.

A new practice was introduced which requires newsboys to renew their 
badges annually and this accounts for the large increase in the number of boys licensed. The plan has worked well, the boys have given less trouble about wearing badges and it has been easier to determine whether the badges were issued to the boys using them. Of course the reissuing of so many badges takes time, but we believe the improved conditions justify the extra work.

The physical examinations of children applying for employment certificates continues to be unsatisfactory. The law provides that before an employment certificate can be issued the child must present a certificate from a school physician showing that the child has undergone a thorough physical examination. The present method is to send these children to the offices of the school physicians, dividing the number as equitably as possible among the different doctors. Children spend considerable time in getting to the physician's office. They often have to wait for the doctor to come in, or wait until the doctor has disposed of his regular patients. Usually the physician is rushed and only gives the child a most superficial examination. The doctors dislike to be bothered, children are delayed in getting their employment certificates and they do not receive the protection which the law intended to give them. If a physician could be employed to devote one hour a day to examining children at the certificating office, the faults of the present system would be largely obviated. If this is not possible, a conference between the health department and school physicians might result in their willingness to give one hour in every two weeks at the certificating office to be saved the annoyance of havingechildren sent to their offices.

The ceneus data shows increase over the preceding year of 838 children between five and sixteen years of age. Home visits have tended to promote fine school and home co-operation. Thus a high percent of attendance has been secured. 
The following is taken from the report of Mr. Charles L. Mosher, Director of the attendance division of the Rochester, New York schools.

"It is clear enough that boys and girls who are absent from school cannot during their absence receive the instruction which the school has to offer and which the taxpayers have provided. It is also clear enough, at least to teachers, that nothing interferes more with the success of the pupil and the success of the school than absence- loss of school time, loss of touch with the subjects studied, failure to understand on that account facts and processes necessary to the later instruction as it comes along. It follows, of course, that we are not justified in spending huge sums of money to provide educational opportunity and then allowing preventable absence which throws away a large proportion of this value and handicaps the realizing of much more of it.

"The law provides that all children between the ages of seven and sixteen years shall attend school while school is in session. Provision is also made for part time attendance for pupils under seventeen years of age who are not attending full time school".

"The intent of the law is very clear. It seems to insure t'o every child his opportunity for a common school education. It says very plainly that this shall not be interfered with by accidents or birth or home conditions. It means that neither poverty nor ill luck or illness on the part of parents nor any other circumstances shall prevent boys and girls from having the fundamental instruction which they need. It places squarely upon the community, if parents are unable to meet the obligation, the duty of seeing that this opportunity is open.

"The broad basis to which we must look for success in carrying out the provisions of this law is primarily the interest and the attitude of the individual 
teacher. It is the attitude of the teacher and the regular attendance or the irregular attendance which results therefrom which makes the enforcement of the law possible or very difficult, if not impossible. Most teachers appreciate this. In many cities, villages and districts boys and girls have the keenest pride in the record of attendance which their group is able to make and with some exceptions superintendents, principals, teachers, boards of education and parents appreciate this point of view and encourage and promote it in every possible way. Children are interested in a mild but very useful form of competition so that we find here and there plans which recognize in some way the fine records of attendance which various groups are able to make. This recognition is quite worth while. It focuses attention upon an important matter. It emphasizes this matter in a way which catches the imagination of youngsters and thus secures results from them. In many cases it enables the instruction of parents, needed in not a few instances, so that they come to understand that irregular attendance is fatally destructive to good school work and are thus glad to cooperate with the school authorities, even to the extent of arranging vacations and other situations, which are likely to break into school time, in such ways as to reduce losses to a minimum.

"Perhaps the most important result is the right spirit on the part of the girls and boys and their parents toward school attendance comes from the fact that it makes the duties of the attendance officers possible of accomplishment. Where a lax situation results in a flood of illegal absences the attendance officer is confronted with serious difficulties. He deserves considerable sympathy and he should be correspondingly thankful where, as is right and proper, the cooperation of the teacher, pupils, and others, results in the number of actual infringements of the law being small enough to enable - him to give each one the detailed and careful attention which it needs. 
"And while speaking of the attendance officer, may I say that I have found a strong and widespread interest in the formation of local groups of such officers for mutual assistance and for the consideration of many difficult problems common to all; and the further idea that these groups should be united to form a state association either connected with the State Teacher's Association or inde pendent of it, as may be found the best. I know of no field where the rewards of such organization for study, for the exchange of ideas and experiences, for the setting up of common, acceptable standards, for the discussion and for the determination of exact procedure would be greater. The value of getting together and realizing the power of such a group for improving conditios and efficiency of the job in which all are interested is in these days perfectly well known. "In order that the attendance department shall understand about the enforcement of the compulsory law it is necessary that they know, first, the children involved, which should be shown by the census; second, whether these children are in touch with the schools, which should be shown by checking the census with the enrollment and registration; third, whether the pupils thus registered are in regular attendance at school or not, which would be shown by the percentage attendance which each given unit may secure month by month. Monthly attendance reports are now made in practically all school districts. It is planned with the next school year to handle these reports in a way that will enable the attendance department to return to each supervisory district the records of each group month by month so that the officer in charge may ascertain just what progress is being made as compared with other districts and previous years. 
"A great deal of the difficulty of attendance arises from poverty or illness. The cooperation, in connection with these conditions, of health officers, medical inspectors, school nurses and physical education directors and teachers is of immediate and practical value in enabling the boys and girls to maintain their attendance in school.

"The assistance of the courts where conditions otherwise unsolvable are found is of the very first importance. It is rendered in proportion as this importance is understood and it should be the aim of all school administrators to secure the cooperation of the courts which they are almost invariable glad to give when facts are presented to them in clear-cut fashion so that they may understand what the enforcement of the law means to all concerned.

"The cooperation of school authorities with the various welfare agencies has been far less than it should be. Attendance is often interfered with by home conditions, which, if persisting, continue to make good school work impossible on the part of the child involved. What is more logical and sensible than that the school people concerned should cooperate to the end that the fundamental causes and conditions which make attendance impossible be removed and the child restored to the way of normal happiness and progress which is his birthright".

Rochester readily recognizes the correlation of non-attendance and poor health as demonstrated in the accompanying summary, which shows the diseases found in the past three years.

\begin{tabular}{lcrr} 
DISEASE & $\frac{1925-56}{42}$ & $\frac{1926-27}{48}$ & $\frac{1927-28}{189}$ \\
\cline { 2 - 3 } Lung & 20 & 45 & 74 \\
Head, throat, eye and ear & 89 & 95 & 173 \\
General & 87 & 132 & 311 \\
Nerves & 69 & 93 & 124 \\
Mental & 37 & 2 & 32 \\
Bone and joints & 32 & 56 & 118 \\
Heart & 49 & 52 & 71 \\
\multicolumn{1}{r}{ Total } & 425 & 523 & 1,092
\end{tabular}




\section{CHILDREN'S COURT}

Children's Court Committments

$1924-25$

25
$1925-26$

33 $\underline{1926-27}$

38
$1927-28$

60

Children's Court Cases By Schools

\begin{tabular}{|c|c|c|c|c|c|}
\hline School & Number & Number & \multicolumn{2}{|c|}{ Number } & \multirow{2}{*}{$\begin{array}{c}\text { Number } \\
1927-28 \\
\end{array}$} \\
\hline & $1926-27$ & $1927-28$ & & $6-27$ & \\
\hline 3 & 1 & & St. Boniface & & 1 \\
\hline 4 & 1 & 1 & Mt. Carmel & & 1 \\
\hline 5 & 3 & 3 & Our Lady Victory & & 1 \\
\hline 6 & & 1 & St. Stanislaus & & 4 \\
\hline 9 & 6 & 5 & H. Redeemer & & 1 \\
\hline 10 & 1 & ? & Corpus Christi & 1 & 2 \\
\hline 12 & 1 & 1 & Wash. Jr. & & 4 \\
\hline 14 & 3 & & Mad. Jr. & 2 & 4 \\
\hline 17 & 5 & 3 & East High & & 1 \\
\hline 18 & 1 & 3 & Jefferson Jr. & 1 & 3 \\
\hline 20 & & 1 & W. Prevocational & & 2 \\
\hline 21 & & 2 & Continuation & & 2 \\
\hline 24 & & 1 & West High & 1 & \\
\hline 25 & 2 & 2 & Rochester shop & 1 & 1 \\
\hline 26 & 3 & 1 & Boys Prevo. & 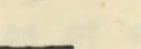 & 1 \\
\hline 27 & 4 & 4 & & & \\
\hline 29 & & 2 & TOTAL & 38 & 60 \\
\hline 33 & 1 & . & & & \\
\hline 39 & & 1 & 1 & - & \\
\hline 42 & & 1 & 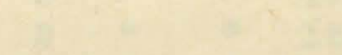 & & \\
\hline
\end{tabular}

Children's Court Cases By Ages

Ýear

7

8

9

10

11

12

13

14

15

16

17

\begin{tabular}{|c|c|c|c|}
\hline \multicolumn{4}{|c|}{ Boys } \\
\hline 1926 & -27 & 1927 & -28 \\
\hline & 0 & & 1 \\
\hline & 0 & & 1 \\
\hline & 1 & & 0 \\
\hline & 1 & & 0 \\
\hline & 7 & & 2 \\
\hline & 4 & & 5 \\
\hline & 10 & & 5 \\
\hline & 4 & & 3 \\
\hline & 4 & & 10 \\
\hline & 0 & & 4 \\
\hline & 0 & & 1 \\
\hline
\end{tabular}

\begin{tabular}{|c|c|c|c|}
\hline \multirow[b]{2}{*}{1926} & \multicolumn{3}{|c|}{ Girls } \\
\hline & -27 & 1927 . & 28 \\
\hline & 0 & 0 & \\
\hline & 0 & 0 & \\
\hline & 0 & 0 & \\
\hline & 0 & 0 & \\
\hline & 1 & 1. & \\
\hline & 0 & 2 & \\
\hline & 3 & 3 & \\
\hline & 0 & 6 & \\
\hline & 3 & 10 & \\
\hline & 0 & 6 & \\
\hline & $\underline{0}$ & 0 & \\
\hline & 7 & 28 & \\
\hline
\end{tabular}




\section{Children's Court Cases By Nationality}

\section{$\underline{1926-27 \quad 1927-28}$}

Italian

Polish

American

Syrian

German

Irish

21
1
2
0
6
0

30
13
8
0
4
0

$\underline{1926-27}$

$1927-28$

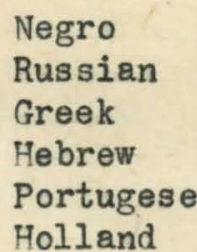

TOTAL
1

1

$0 \quad 0$

$0 \quad 0$

6
6

$0 \quad 0$

$1 \quad-0$

$38 \quad 60$

\section{STUDY OF TRANSFERS}

There were 4060 transfers made in the school year 1926-27. 178 transfer cards were imperfect. 2,772 Transfer cards with no time lost. Out of 200 no time lost cards $37 \%$ were cases of schools far apart and $63 \%$ were cases of schools nearby.

1110 transfer cards with time lost. Out of every 100 of these lost time cards (one day) $48 \%$ were schools far apart, $52 \%$ were cases of schools near-by.

\begin{tabular}{|c|c|c|c|c|}
\hline 16 & cases & lost & $\frac{1}{2}$ & day \\
\hline 362 & " & " & 1 & " \\
\hline 3 & " & " & $1 \frac{1}{2}$ & " \\
\hline 193 & $n$ & $"$ & $2^{-2}$ & " \\
\hline 3 & " & " & $2 \frac{1}{2}$ & " \\
\hline 107 & $"$ & $"$ & $3^{2}$ & " \\
\hline 133 & " & " & $3 \frac{1}{2}$ & n \\
\hline 75 & " & $"$ & 4 & $"$ \\
\hline 48 & " & $"$ & 5 & " \\
\hline 10 & " & $"$ & 6 & $n$ \\
\hline 23 & " & $"$ & 7 & $"$ \\
\hline 27 & " & $n$ & 8 & n \\
\hline 19 & " & $\oplus$ & 9 & " \\
\hline 6 & " & " & 10 & " \\
\hline 3 & " & $"$ & 11 & " \\
\hline 8 & " & $"$ & 12 & $"$ \\
\hline 6 & " & " & 14 & " \\
\hline
\end{tabular}

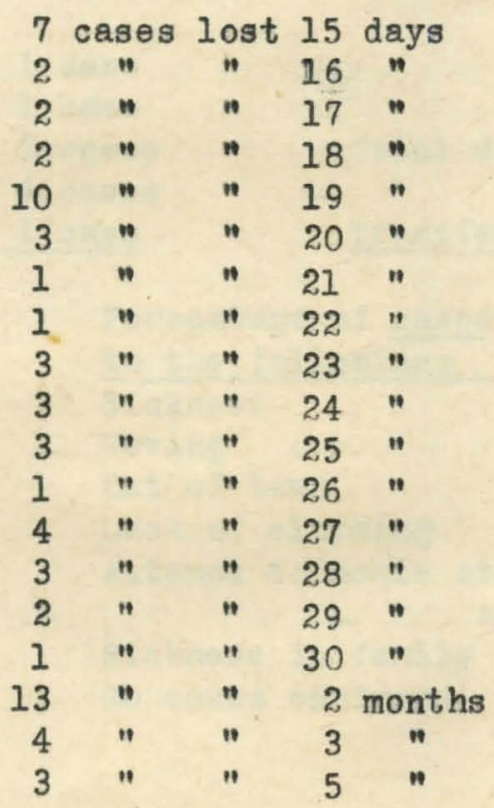

THERE WERE 5,341 DAYS LOST IN

TRANSFER. 
Individual CAUSE of Loss In Transfer

Sickness

1 day 5 cases

2 days 3 cases

3 days 1 case

4 days 5 cases

5 days 6 cases

8 days 1 case

21 cases. 72 Total days lost for sickness.

Out of Town

I day I case

10 days 1 case

29 days 1 case

3 cases, 40 toal days

lost. for out of town.

Lack Of Clothing

2 days ' 1 case

3 days 5 cases

6 cases, 17 total days lost for

lack of clothing.
Moving

1 day 15 cases

2 days 6 cases

3 days 1 case

4 days 5 cases

5 days 3 cases

7 days 1 case

31 cases. 72 total days

lost for moving.

Attempt To Locate In Other Schools

1 day

3 cases

2 days 3 cases

3 days 2 cases

4 days 4 cases

7 days 1 cases

13 cases, 38 total days lost in attempt to locate in other schools.

Sickness in Family

1 bay 5 cases

9 days 4 cases

9 cases, 41 total days lost

for sickness in family.

No Cause Assig ned

\begin{tabular}{|c|c|c|}
\hline 1 day & 51 & cases \\
\hline 2 days & 19 & cases \\
\hline 3 days & 21 & cases \\
\hline 4 days & 7 & cases \\
\hline 5 days & 6 & cases \\
\hline
\end{tabular}

Percentage of days lost due to the following:

\begin{tabular}{lc} 
Sickness & $12 \frac{1}{2} \%$ \\
Moving & $12 \frac{1}{2}$ \\
Out of town & 7 \\
Lack of clothing & 3 \\
Attempt to locate other & \\
\multicolumn{3}{c}{ schools } & 7 \\
Sickness in family & 7 \\
No cause assigned & $\frac{51}{100 \%}$
\end{tabular}

$\begin{array}{r}6 \text { days } 1 \text { case } \\ 7 \text { days } 1 \text { case } \\ 8 \text { days } 2 \text { cases } \\ 10 \text { days } 4 \text { cases } \\ 11 \text { days } 1 \text { case } \\ \hline\end{array}$

Total days lost in

transfer 570
Percentage of cases lost due to the following:

\begin{tabular}{lc}
\hline Sickness & $10 \frac{1}{2} \%$ \\
Moving & 16 \\
Out of town & $1 \frac{1}{2}$ \\
Lack of clothing & 3 \\
Attempt tolocate other & $6 \frac{1}{2}$ \\
\multicolumn{1}{c}{ schools } & 4 \\
Sickness in family & $4 \frac{1}{2}$ \\
No cause assigned & $\frac{58}{100 \%}$
\end{tabular}


In the annual report of the Department of Attendance, Detroit, Michigan, A. N. Hennigar states that the law provides that all children from the ages of seven to sixteen years must attend school during the entire term as established by the school board of the district where they reside. An exception is made in cases where school is in session for twelve months, in which case the children must attend for a minimum of nine months.

The following classes of children are not required to attend school:

1. Those who have received an eighth grade diploma from a public, private or parochial school and who are regularly employed at some lawful work and a rephysically able to work.

2. Those who are physically unable to attend school.

3. Those who are over fourteen years of age and have completed the work of the sixth grade and whose services are necessary for the support of the family.

4. Those who are regularly employed as a page or messenger of either branch of the state legislature.

5. Those who are under nine years of age and whose parents live more than two and a half miles from the nearest public school unless transportation is provided for pupils in such districts.

The attendance officer in Detroit is no longer an old-fashioned "hookey cop" who used to chase down the alley for the fleeing truant. He now uses entirely different tactics to capture the truant and remedy the existing cause. For instance, he considers the type of child with whom he is dealing; what kind of physical and mental make-up he possesses; and the nature of the environment in which he lives. He will then seek to remove any obstacles that might prevent an adjustment among the child, school and home. 
Furthermore, the family may be so poverty-stricken that proper clothes cannot be furnished the children in order to permit them to attend school. The attendance officers solve, this problem by applying to some welfare or social service agency for aid.

Occassionally pressure needs to be brought to bear upon the parents because of the indifferent or neglectful attitude they take toward their children. Sometimes, upon investigation, the home environment may be ideal, but the child is a chronic truant. This may be due to a lack of capacity because of the age of the child, or the child may be so far below his capacity that he must find bther means for absorbing his superflous energy - A psychological test is given and if this throws light on a solution the child is placed in a special room. He soon develops an interest in his work and before very long needs no further coaxing for regular attendance. Effecting a satisfactory adjustment usually insures regular attendance on the part of the child. On the following pages are forms used by the Attendance Department of the Detroit Schools. 


\section{DETROIT BOARD OF EDUCATION DEPARTMENT Of ATTENDANCE}

Detroit, Mich., 19

Sehool

Pupil's Name

Residence

Date of Birth Grade

Guardian's Name

HISTORY-(Give full history of the case as to the general behavior, home influence, associates, record of attendance, etc.)

Absent (Give Dates)

Absence this Semester Half Days

Times Reported

Principal

\section{Report of Attendance Department}

Received 19 Investigated 19

Interview $\left\{\begin{array}{l}\text { Time } \\ \text { Place } \\ \text { Persons }\end{array}\right.$

Cause of Absence

Disposition

Attendance Officer

\section{Report of Principal}

Child Returned to School 19

Principal

\section{Instructions for Principals}

The yellow slip is for the officer.

The white slip is for your records.

The pink slip is for the records at the Department of Attendance.

Form 27-Absence Report-8.28-225M-UU-HRW 


\section{BOARD OF EDUCATION}

ATTENDANCE DEPARTMENT

No.

\section{Non-Attendance Permit}

This is not a "Working Permit" or "Age Certificate."

Name of Minor

Residence

Date of Birth

Place of Birth

NotE: This minor is required to attend Continuation School eight hours a week until he or she is seventeen years of age.

Minor's Signature

Permit Expires

Detroit, Mich.,

Issuing Officer

By

Form $438-7-27-5 \mathrm{M}-\mathrm{P}$ 


\section{DETROIT BOARD OF EDUCATION \\ Department of Attendance, 814 Bates Street \\ NOTICE TO PARENTS OR GUARDIAN}

To

You are hereby notified that

a child under seventeen years of age and under your legal control, is not attending school as is required by Act No. 421 of the Public Acts of 1919 as amended. You are hereby directed to send said child to the continuation school

on , and you are further notified that said child must be in regular attendance at continuation school until he reaches the full age of seventeen years.

Yours respectfully,

Attendance Officer.

Served on

Detroit, Michigan

Failure to comply with the above act is punishable by a fine of not to exceed $\$ 50.00$ or imprisonment in the County Jail or House of Correction for not to exceed 90 days or both such fine and imprisonment.

Form $427-8-28-10 \mathrm{M}-\mathrm{S}$ 
Acc ording to Mr. Joseph $\mathrm{W}$. Hobbs of the attendance department, Boston, Massachusetts, statistics have proven that in practically every case of serious delinquency, truancy has been the first violation of the law committed by the individual child. Truancy in itself is not a crime, but it is a condition very fruitful in the production of criminals.

The Boston Disciplinary Day School (for boys) was established especially for habitual truants, absentees and school offenders. Itndesigned primarily for the protection of the child, not his detriment; a hospital where boys morally sick are not to be degraded or pampered, but treated; not to be punished simply for punishment's sake but restricted in their liberty for the welfare of society, yet afforded every opportunity for a wholesome development. The children in the disciplinary school are not always sent for punishment but often for adjustment. These boys are misfits in the system of education and because they are misfits, due mostly to home conditions, they have taken up their lives in the streets, obsenting themselves from school and violating the rules and regulations. The school admits only boys. They are sent to the school from all parts of the city and range in age from nine to sixteen years. They are admitted from all grades and from the continuation school. The primary children are usually over grown or over age for their grades. The boys in the higher grades are those who have reached their mental capacity. Grade work is a little beyond their limits and as a result they react in a negative manner. On the other hand there are boys who do like school work but they have had a misunderstanding of some kind or perhaps they have taken a dislike to a certain subject or some phase of their work. The program of the school is varied, flexible and understandable and one which interests all boys. Manual arts, physical education and agriculture 
in the way of home gardening contribute in making up the variety of subjects. Most of the pupils are from broken homes where one or both parents are dead or separated, or from homes where the mother is working. During the past school term, $1926-27$, there was an enrollment of 226 boys. Fifteen percent had no mothers, fifteen percent had no father, three percent had lost both parents, three percent were children of parents who had been divorced, thirtytwo percent had mothers who worked, three percent were living with guardians who worked, and a total of seventy-one percent lacked normal home life.

Children reported as needing special class work are of two types: first, the children of such low mentality that they cannot profit by attendance of public schools; second, children who have not succeeded in their ordinary class but who are nevertheless educable provided their work is adapted to their mental attainments.

The typical class has fifteen pupils selected from the first three or four grades, ranging chronologically from seven to eleven years of age and mentally two or three years retarded.

The Boston public schools are giving these children new life and new hope, new ambitions and new virtue, by effective, systematic organization and by a careful classification of defects.

The methods of enforcing the compulsory school attendance law are based on the general assumption that truancy and the related evils of irregular attendance should be investigated and corrected by a staff of attendance officers directied by a central authority.

Efforts have been made, especially during the past two years, to bring - the influence of the school to bear on careless and indifferent parents, by 
requiring them to explain, at the school, and in the presence of the principal, the causes of the non-attendance of their children.

The persistent policy of appealing to the parents to secure compliance with the law does not imply that the department will not appeal to the court to impose penalties when indifferent and carelss parents obstinately refuse to keep their children in school. When persuasion fails proper and necessary measures must be invoked and carried out to a successful conclusion.

The record of the attendance department of the city of New Orleans, Louisana, is as follows:

\section{Scope of work}

a. Enforcement of compulsory attendance and child labor laws.

b. Issuing of employment certificates to minors, ages 14 to 16 and of age cards to children over 16.

c. Taking of school census.

\section{Objectives}

An analysis of the absence cases passed upon by the department during 1925 shows that one third of the cases were due to carelessness of parents. Evidently there is such a vast change in home life that the result is isfifieant of a lowering of standards and a looseness of control by the parents so that one is brought to the test of real social problems with the boys and girls. The correcting of this evil is one of the serious problems confronting the attendance department.

The main object of the department is to get minors in school and keep them there, whether of legal age or not. The department also tries to persuade minors who apply for employment certificates to remain in school in order to provide themselves with better qualifications for employment.

Attendance officers are directed annually to take a census of all minors in their districts whose attendance at school is obligatory. At the opening of the school term the officer must see that all minors are enrolled except 
those who are legally employed or those legitinately absent. The principal of each school is required to send a daily card for each pupil that is absent from school without a valid excuse. The officer calls at the home of the child for an explanation of the child's absence; a report is made to the principal of the finding. In case of repeated absences a letter is sent to the parent asking him or her to call at the office of the director of attendance for an interview concerning the child's absence.

If all efforts have failed to keep the child in school he is cited to appear before the Juvenile Court, which either paroles him or commits him to the county institution for delinquent minors. A close follow-up is made of all those who go before the court to see that they do not return to their old habits of truancy.

Employment certificates are issued to minors who are over sixteen and who furnish satisfactory birth record and who have, with their parents, been interviewed by the department of vocational guidance and who have been passed upon by the medical examiner and have complied with all the provisions of the child labor law.

The following statement shows a summary of the work done by the department during the years 1921-1925.

Number cases absence reported, (all schools) -

Number of cases of absence having legal excuse-n-

Number of cases of truancy reported first time-_.

Number of cases of truancy previously reported-a 815

Number of cases absent through neglect of parents-_-

Number cases parents served with legal notice-1.

Number of cases referred to director of the department-_...-..- 785

Number committed to juvenile court- 101

Number of cases of non-attendants placed in school-_... 82.9

Number of cases illegally employed, returned to school-_-_-_-_- 215

Number of cases reported to department of charities-_... 99

Number of prosecutions entered against parents- 384 
A survey of the attendance department of Portland, Oregon, supervised by Mr. Charles A. Fowler, Jr., states that the operation of the department is based upon the idea that there is an underlying cause for truancy or irregular attendance, and further, that it is idle to attempt treatment of truancy or irregular attendance which does not include searching out of this cause and correcting or removing it. It is impossible to do detailed work in each instance and there are a great many purely spasmodic cases which do not require detailed treatment, but the principles stated above are the general background of service. A classification of the underlying causes which have engaged the attention of this department has been made this year, In certain cases a combination of causes rather than any single one appeared to be the cause of the difficulty and with these the cause most predominant was selected for tabulation. The tabulation itself follows:

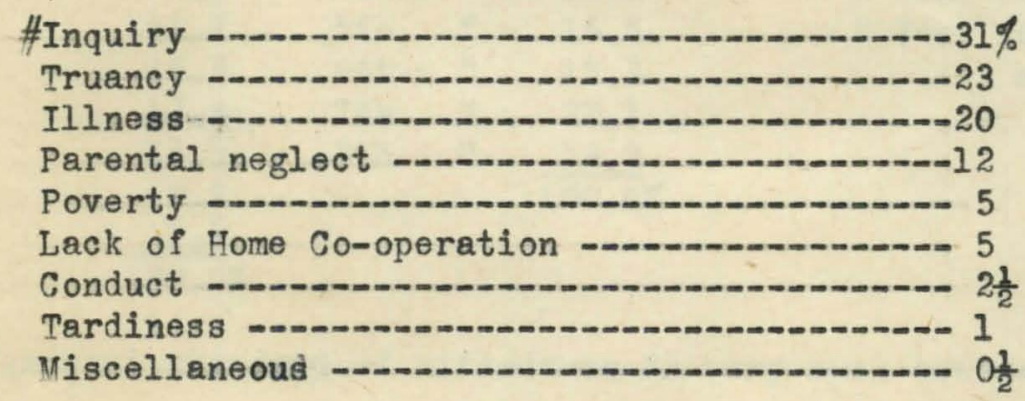

\# Cases referred and investigated showing no cause for further attention from this department are classified as Inquiry.

In the itemized tabulation of the year's activities which follows, the noteworthy feature is the continued decrease of the number of court cases. This is due to the splendid co-operation of the various social agencies and other educational departments.

The report is as follows: 
Number of cases handled....Boys - 2,658, Girls - 1,084, Total $--3,742$

Letters to parents

Number of calls made

Number of cases referred to district attorney

Number of cases filed in court of domestic relations -

Number of cases referred to Womens Protective Division -...-.- 6

Number of cases referred to court of domestic relations -...-. 28

Number of cases referred to Child Welfare Commission -...... 2

Number of cases filed in district court

Number of cases referred to Public Welfare Commission -...... 1

Suspensions -

Legal notices sent to place child in school

Physicians certificates received $\quad$ Night 55

Special investigations

The following chart shows the percentage of retardation by ages and by grades:

\section{BY AGES}

8 years or less

9 "

$10 "$

$11 "$

$12 "$

13 "

14 "

$15 "$

$16 "$

17 "

\section{BY GRADES}

$\begin{array}{ll}\text { lst Grade } & 2.5 \% \\ \text { 2nd " } & 4.8 \\ \text { 3rd " } & 8.4 \\ 4 \text { th " } & 12.0 \\ 5 \text { th " } & 15.6 \\ 6 \text { th " } & 15.3 \\ 7 \text { th " } & 22.1 \\ \text { 8th " } & \frac{19.3}{100.0 \%}\end{array}$

\section{SHOWING RETARDATION}

1 Year adv. $\quad .7 \%$

Normal 25.6

1 Year ret. 32.0

2 Year ret. 26.0

3 Year ret. or more $\frac{15.7}{100.0 \%}$

The general standard of attendance is very much better than formerly.

This may be attributed to the unity of purpose, the splendid organization of the present regime, and the helpful constructive support of all connected with the work.

Samuel W. Fogle, Supervisor of the Departmend of Attendance, Cincinnati; Ohio, explains the methods used in his department to alleviate the problem of non-attendance in the following manner. The attendance officers report to their respective schools the first thing each morning to receive the cases of non-attendance from the principal or the person in charge of the attendance 
records of the school. An immediate investigation is made to ascertain the cause of the child's absence.

The causative factors are generally poverty or antagonism on the part of the parents and truancy, the latter representing a very small percentage of the absentees, estimated at five or six percent. There is no doubt but that there is a considerable amount of mental defectiveness among this group of people, although it is evident that the principal causes of nonattendance are poor health on the part of the child or some member of the immediate family and poverty. On the other hand there is an indifference or laxity on the part of the parents to keep their children in school with any degree of regularity. Quite frequently a child is kept home to take care of younger brothers or sisters while the parents are working and in some instances they are kept at home to help with the family washing and other domestic work. It is not infrequent to have the parents encourage the child to remain out of school and seek illegal employment.

The Gincinnati department does not use very stringent methods with parents and children unless they have a case of open defiance or antagonism on the parts of the parents. Through preyen tive and curative work an effort is made to bring about cooperation between the child, the home and the school. Court action is only resorted to in the most extreme and aggravated cases. A reduction of sixty percent has been made in the references to the juvenile court.

Austin. N. Miller of the division of attendance, Harrisburg, Pennsylvania, says that the percentage of attendance for the past year, 1927-1928, was $94.7 \%$ and that there was an average daily attendance of 12,308. The pupils enrolled during the year missed 128,645 days of schooling. The percentage of attendance 
obtained is spendid but when analyzed as to cases there were 680 pupils absent from school daily. Ninety-three and a half percent of all absences were excused and a large part of this absence is attributable to sickness or alleged sickness. Truancy only constituted seven-tenths of one percent of all absence. There is a loss and waste in all business organizations and the employers of labor are constantly striving to find the leaks. An article recently published contains the following: "Regularity of attendance at one's post of duty is one of the measures of efficiency and few habits that the school can build have a more direct relation to success in life". An article by Mr. I. I. Caldwell contained the following: "It is no longer good business to take ahsence for granted. Absence is waste and as a loss it must be eliminated. The most serious results of absence and tardiness are the by-products of indifference to opportunity and the habit of irresponsibiltty. Success or failure in life depends largely upon one's habits. Habits formed in childhood are likely to be carried through life. Being in the right place at the right time is a most desirable habit in any occupation or profession". Absence from school is a waste and it behooves school authorities and parents to do everything in their power to eliminate it.

There were 1,639 pupils who were neither tardy nor absent during the school year. The total number of pupils enrolled showed an increase of 119. The senior high had an increased enrollment of 63 pupils and the junior high schools an increased enrollment of 99 pupils.

The teacher's report the following reasons for non-promotion of their pupils: backwardness, 403; mental, 123; physical, 85; irregular attendance 160; and other causes, 288 .

The chart on the following page gives a summary of the attendance and nonattendance in the Harrisburg public schools. 


$\begin{array}{rlrr} & \text { (Excused } & 231,083 & 239,256 \\ \text { Number of sessions of absence } & \text { (Parental neglect } 24,420 & 24,095 \\ & \text { (Illegal employment } & 86 & 272 \\ & \text { (Truancy } & 1,861 & 2,645 \\ & \text { (Total } & 257,447 & 266,268\end{array}$

Aggregate days attended -

Aggregate days belonged -

Percentage of attendance

Number of sessions of unlawful absence

Number of notices served on parents

Number of arrests of parents

Number of convictions

Number of pupils sent to institutions by

the court
94.7

18,001

723

44

36

19

40
$2,306,964 \frac{1}{2}$

$2,440,098 \frac{1}{2}$

94.5

18,859

782

52

42

16

Number of pupils sent to house of deten-

tion by attendance bureau

-...--

Mr. William M. Bodine of the Attendance Department, Chicago, Illinois, states that attendance is the supreme fundamental of education. It is the "ace" of the school welfare but we have a "deuce" of a time making some parents believe it.

Among the destructive factors of attendance is the indifferent, intemperate, incompetent parent, and the unsanitary home that creates an environment conducive to truancy and juvenile delinquency. Attendance is often handicapped by mental misfits and depressive victims of grade retardation. Here lies the value of psychological research and child study.

Mental hygiene is a product of progressive sociolology and is fast expanding into one of the outstanding features as a constructive necessity in 
child conservation and attendance.

Wife desertion is one of the greatest causes of truancy. It forces mothers into indutrialism and they have not the time to care for their children. The popular personality of teachers who understand children promotes attendance. She inculcates the lovable and loyal school spirit into the hearts of the pupils. But a neurotic, autocratic and aublmatic teacher with a sour face añd mean disposition creates truancy.

The "conference" plan at schools or in attendance departments between principals, parents and juvenile offenders obviates prosecution in many cases. It goes a long way in promoting attendance and correcting truancy. The effect of non-attendance is disastrous to educational progress as truancy itself. Whether the child's absence is 'sanctioned by the parents or in opposition to their wishes, the effect upon school life is the same. The child missesk school session, falls behind in his school work and suffers the demoralizing consequences of irregular attendance.

There are three distinct types of children who, although not definitely classed as truants, present a similar problem for the attendance department. First, children of newly arrived immigrants who in some cases remain unknown to school authorities for a considerable time after their arrival; second, the children in families who have moved to the city from the country and have found it more convenient, pending discovery of the proper school in which to enroll their child, to keep the child at home; third, children who take transfers from one school to another and then delay their enrollment at the second school. The transfer problem involves irregularity of attendance as well as a wholesale escape from school. Also the inaccuracy of records, as well as the follow-up of transfers, 
shows not only that time is lost but also something of a waste that is so evident from frequent transfers. In a survey undertaken of two schools an effort was made to ascertain causes, effects and results of truancy and nonattendance.

In a West side school, during sixteen weeks, six per cent of the eightysix absent children, whose homes were visited, were absent forty half days or more; that is, they lost the equivalent of four weeks of time during the school session. Twelve per cent of the children were absent thirty half days or more; that is they lost three weeks of the school term. Fifty-six per cent lost two weeks or more.

In a North side school, where the records covered twenty-four weeks, six per cent of the three hundred and six children who were absent, lost sixty half days or more which is equivalent to six weeks or one fourth of a school term. Eleven per cent lost the equivalent of five weeks of school. Eighteen per cent lost the equivalent of one month. Twenty-nine per cent lost the equivalent of three weeks and fifty per cent lost two weeks or more of school time. It is of course important to know whether the cases of children absent several half days, were regular or irregular. The long absence of several consecutive days is usually due to illness, whereas the irregular absences, an occasional half day or day, are more likely to be founded on some trivial excuse.

A very important factor to be considered in Chicago is the amount of English spoken in the home. The following table is typical:

\begin{tabular}{lcr} 
LANGUAGE OF HOME & NUMBER & PERGE \\
\cline { 2 - 3 } \# Foreign & 767 & 70 \\
English & 255 & 23 \\
Both, foreign and English & $\frac{79}{7}$ & $\frac{7}{100}$
\end{tabular}


\#Polish, Italian, Yiddish, Bohemian, Slovak and German are the principle foreign languages referred to in the chart on the preceding page. Another important feature is the social background from which these non-attending children come. First is the question of poverty in the home. Second the question as to what extent non-attendance is caused by the fact that the mothers of these children are widows and obliged to support their children by working away from home.

REASONS GIVEN FOR THE NON-ATTENDANGE OF 1,158 BOYS AND GIRLS WHOSE SCHOOL ABSENGES WERE INVESTIGATED

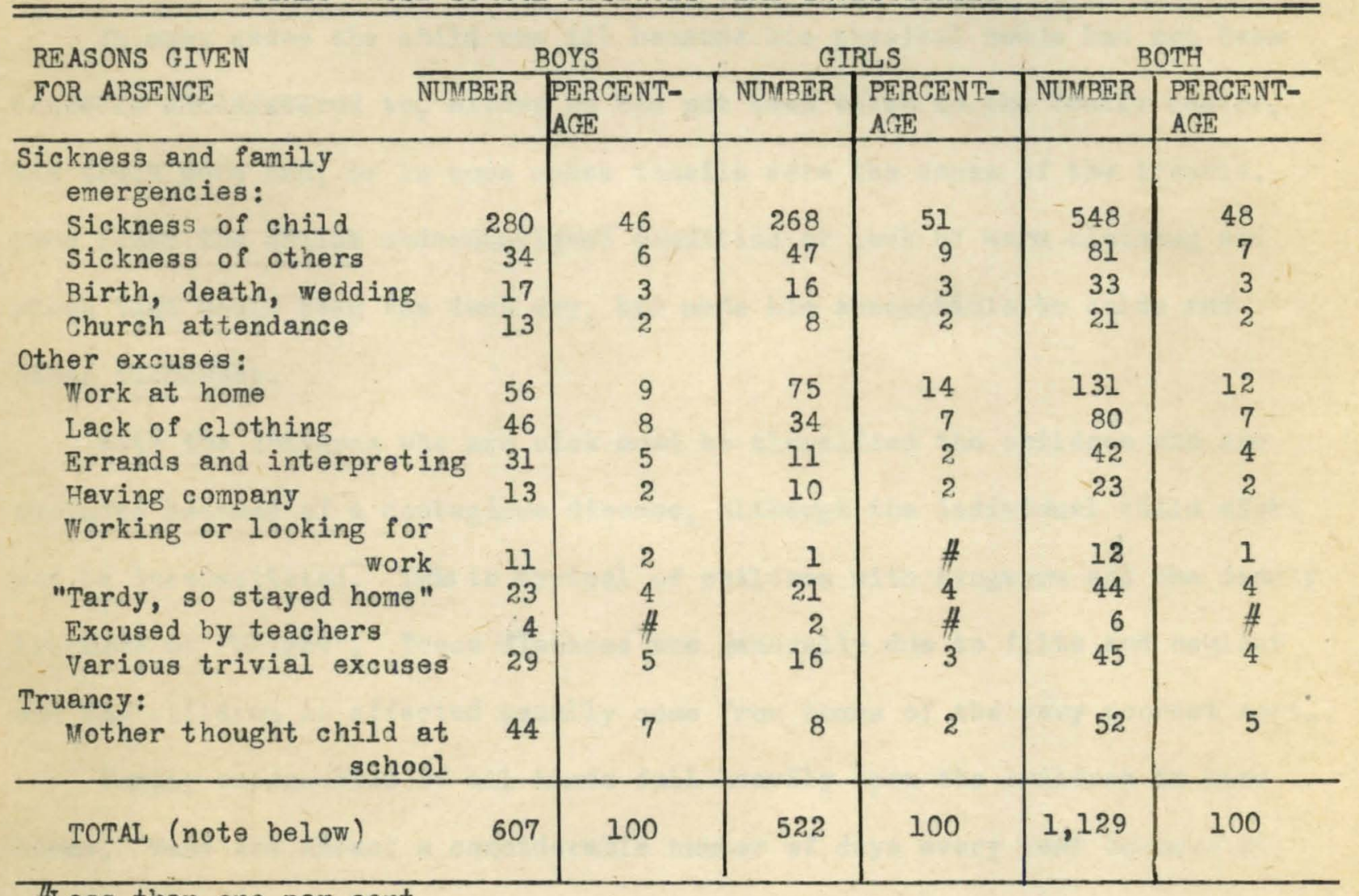

\#Less than one per cent.

Note: in 29 cases, 20 boys and 9 girls, no reason was given for absence.

The various excuses given have been grouped under three heads: absences caused by sickness in the family and family emergencies, which explains a majority of the absences of the whole number of non-attending children; absences 
which could be avoided by little better care and a, little more trouble on the part of the mother, Keeping a child home to run errands, to help with housework and in general to meet the convenience of the mother; absences due to truancy, that is, cases in which the mother had sent the child to school and did not know that the child had not attended.

The great majority of the children absent on account of sickness seem to have had very trivial indispositions. In a considerable number of cases this was found to be merely an excuse for not attending school and not a reason. In many cases the child was ill because his physical needs had not been properly administered to, either he had not been taken to the family doctor, his teeth were bad, or in some cases tonsils were the cause of the trouble. Some times the childs undernourished condition or lack of warm clothing and shoes that would keep the feet dry, had made him susceptible to colds and other illnesses.

With the children who are sick must be classified the children who are excluded because of a contagious disease, although the individual child might not be incapacitated. This is typical of children with ringworm and the deadly trachoma or "blight". These diseases are generally due to filth and neglect and the children so affected usually come from homes of the very poorest sort. Family emergencies of all kinds fall heavily upon the children in poor homes. Many are absent a considerable number of days every year because of the illness of some member of the family. Cases of chronic illness are the most serious and often a child loses a whole year's work because there is no one else to care for a mother or father during a long period of illness.

Furthermore many of the parents are newly arrived immigrants, helpless and ignorant as to the customs of the new land and usually poor. One cannot 
fail to emphasize the fact that poverty is only too frequently the real excuse for non-attendance.

If the absence of the children in the homes where drunkeness on the part of either parent, crime and immorality, cases of wife desertion and filthy living conditions could be reported to the proper corrective agencies at the earliest possible moment, doubtless the problems of delinquency could be solved.

The Juvenile Court states that the great difficulty connected with treatment of girls who are brought into court as delinquent is the fact that the young girl's waywardness and the conditions of degradation so often responsible for her bad conduct are not discovered until too late. Cases of this type indicate the importance of a stricter enforcement of the compulsory attendance laws.

It is very clear that it is the home and the parent, not the child and school primarily, that must be dealt with if the school attendance is to be enforced to the $100 \%$ standard. In an interesting survey made in Chicago of 1,100 cases, less than two per cent of the girls and only seven per cent of the boys were out of school without the consent of their parents. Gareful inquiry seems to indicate that truancy which may be defined as wilful absence on the part of the child without the knowledge and consent of the parent, is a relatively unimportant factor in nonattendance.

- The preceding table shows that only five per cent of the 1,129 nonattending children who were visited were truants, that is children whose mothers did not know of their failure to attend school. Moreover the problem of wilful truancy is almost exclusively a boy problem. 
The law provides for a prosecution of the defiant parent in the municipal court and the committment of the habitually truant child to the parental school through the juvenile court. The theory of the law is that the child will not go to school with the other children in his neighborhood and therefore he must be sent to a special school from which he cannot escape. Such children usually come from homes in which there is a breakdown of family discipline and for this reason the discipline of the parental school is substituted for the lack of control over the children. One child may, because of lack of home training, refuse to go to school at all and may stay away so often as to make it impossible to benefit from the training he does receive on his occasional "visits" to school. Another child, equally undisciplined and lawless, may go to school with fair regularity but behave so badly that the school is of no benefit to him or the other pupils in the class. Although the problem of the child who is guilty of truancy or bad conduct is relatively a small part of the problem of non-attendance, it is nevertheless a serious problem if the large number of boys brought to court on this charge is considered. An attempt should be made to ascertain to what extent the home, the school and the community are responsible for the welfare of the boys. Home conditions are probably the factor of first importance in the problem of truancy. Neglect in the home due to poverty, the death of the father or invalidism of the mother when there is a large number of children, will almost inevitably have a disastrous effect upon the attendance of the children to school.

Poverty is not necessarily the cause of truancy for truancy and 
and poverty alike may be due to one and the same cause, drink or incompetence for example, but truancy has nevertheless a very clear relation to poverty.

Furthermore it is evident that the candidates for truancy are not only poor but many are foreign born or of foreign parentage and as a result have considerable difficulty with the speaking of English. It is hard for the latter class to understand our educational methods and policies and truancy results in no small degree.

PARENTAL STATUS OF TRUANT CHILDREN, 1908-15

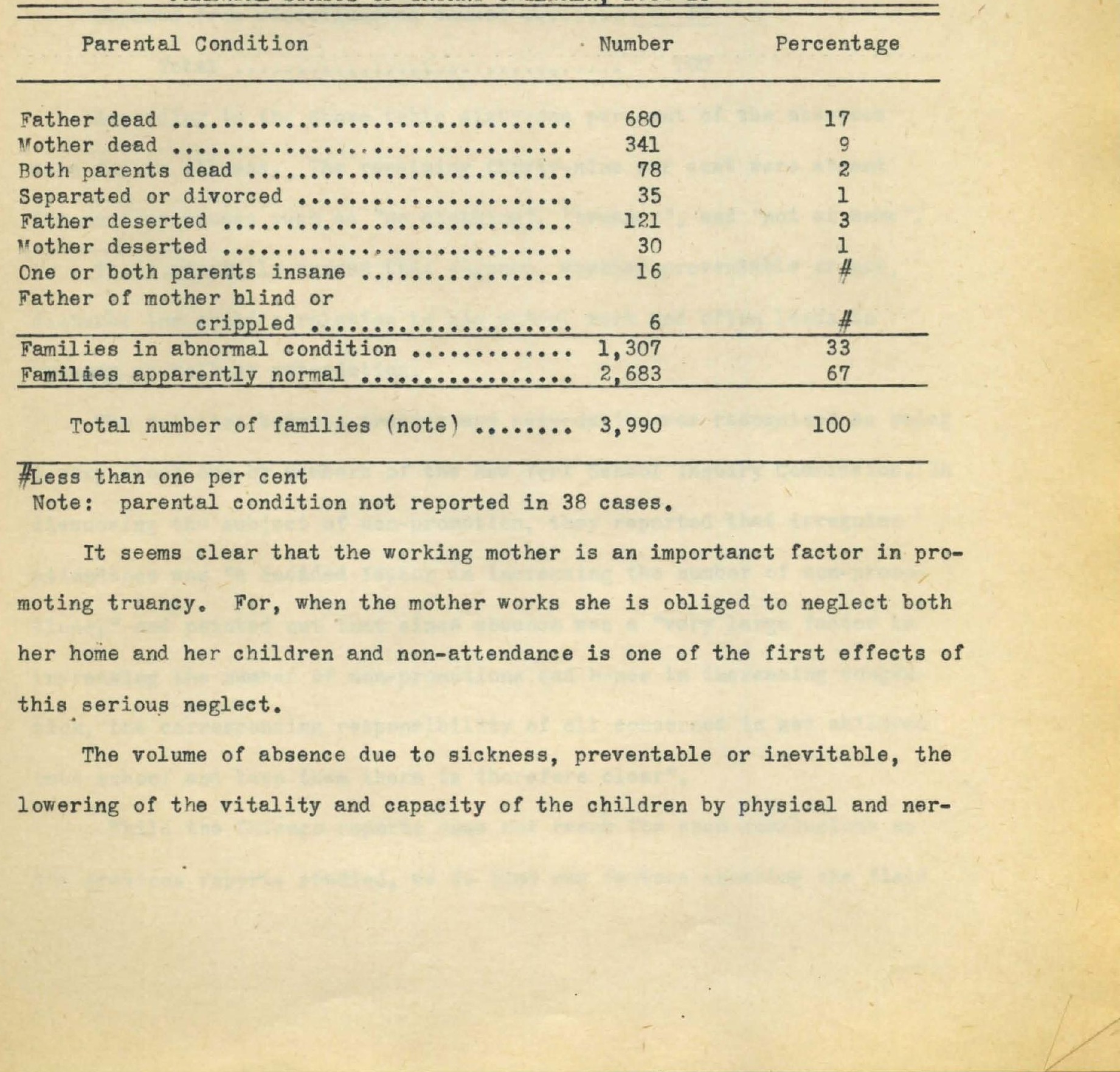


vous defects is a serious educational loss.

\section{PERCENTAGE DISTRIBUTION OF CAUSES OF ABSENGE}

Absent because of illness ............... 61

"Respiratory diseases" ............ 47

"Other severe conditions" $\ldots \ldots \ldots \ldots . .3$

"Vaccination"..................... 2

"Contagious diseases" ............. 4

"Indisposition" $\ldots \ldots \ldots \ldots \ldots \ldots \ldots \ldots, 5$

Absence from miscellaneous causes $\ldots \ldots \ldots$

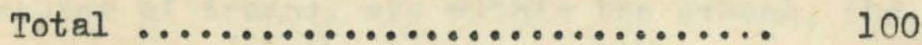

According to the above table sixty-one per cent of the absences were due to illness. The remaining thirty-nine per cent were absent for various causes such as "no clothing", "truancy", and "not at home":

It is generally agreed that absence, whether preventable or not, disturbs the child's relation to his school work and often leads to truancy as well as retardation.

The relation between truancy and retardation was recognized as being a very close one by members of the New York School Inquiry Commission.. In discussing the subject of non-promotion, they reported that irregular attendance was "a decided factor in increasing the number of non-promotions," and pointed out that since absence was a "very large factor in increasing the number of non-promotions and hence in increasing congestion, the corresponding responsibility of all concerned to get children into school and keep them there is therefore clear".

While the Chicago reports does not reach the same conclusions as the previous reports studied, we do find new factors entering the field 
that have not as yet been discovered in other localities. This might be notice to other cities to prepare for these problems while they are yet in their infancy. Chicago is handling the work admirably and in the survey there work has been outstanding as to extent and as to the progress they have made.

Cleveland, Ohio has a Bureau of Attendance and Placement in charge of Geroge E. Whitman. In the report of the bureau it is stated that the problem of truency is so definitely related to the child, the school and the home that these factors must all be adjusted in dealing with the problem. The causes of truancy are within the school, the home (including environment and heredity in general) and either in the mental or physical condition of the child or both. Truancy is but a symptom of maladjustment. Making a proper adjustment, if possible, in any of these three factors would, generally speaking, result in a cure. Furthermore, school adjustment is probably the most important of all since the mental situation will be made satisfactory if the school program is properly adjusted, and the physical defects are immediately corrected.

If no effort is made to adjust a program by which non-attendance can profit, no doubt a great many truants will result.

During the past year there was an increase of two per cent over the previous year in the number of children reported for school irregularities. While teachers frequently desire home information for other reasons than absence, yet absence remains the cheif cause of reference to the department.

The total absence of those reported amounted to 331,261 days or 1,811 school years. This does not include all the absences by any means but only that of the pupils referred to the department. Approximately $30 \%$ is excusable, but the remainder is due to maladjustment in the school, 
irresponsibility of parents and children, environment and economic conditions. Of these, maladjustment in school is responsible for the greater proportion of absence. Until recent years the impression existed that children were absent from school because they were immorally bad. Those close to the problem have become convinced that truancy is a sympton rather than a disease, that if the child can be properly adjusted in his school life as well as at home truancy disappears. Adjustment in school is generally easier of accomplishment than adjustment to environment, since the school factors are more easily controlled. Only when Boards of Education realize the necessity of employing trained workers to assist in solving childhood problems can it be hoped to eliminate the waste of non-attendance and missonduct in the schools.

Contrary to belief the greatest number of truant cases are in the seventh grade where the median age is thirteen years. A number of factors are evident, namely the change from close supervision in the elementary schools to the freedom of the junior high school; short home room sessions and completely departmentalized work.

It may be possible that a considerable number of the delinquencies in later grades could be prevented if more could be done to keep the seventh grade pupils in line.

Homogenous grouping brings the problem child sofwhat quickly into the limelight. Bringing together large groups of adolescents in, the junior high schools makes it possible for the child who is easily influenced to misconduct or who is less stable, to develop activities that do not conform to good school practice. 
In the solution of these more difficult cases it is the policy of the Bureau to make a detailed social study, accompanied by a mental and physical examination, of the child after which the parents are called in for conference.

When a child becomes so maladjusted to his school life that the administrative staff of the school believes that outside assistance is necessary in the solution of the problem, the case is referred to the central office for their consideration.

The form on which the case is reported contains sufficient data concerning the child and his difficulties in the school to serve as a basis for further study of his problem. The child is given a second physical examination and mental test, much more thorough and searching than the first. The most frequent disposition of these cases is to "return the child to school", always on condition that proper adjustment is made. Failure to make such adjustment as recommended results in a recall of the child, transfer to another school or appearance in the juvenile court.

Most of the cases occur in the seventh, eighth and ninth grades and between the ages of fourteen and sixteen years. This seems to indicate that the instability of adolescence is a very definite and real problem to be considered in the adjustment of the child to his school program.

- The following tables and figures give a detailed analysis of absences, by grades, sex; a distribution of the absences in periods and by grades; and a general sumary of the work of the bureau. 
COMPARISON OF ABSENCES BY GRADE AND SEX

\begin{tabular}{l|r|r|r|r|r|r|r|r|r|r|r|r|r}
\hline Grades & 12 & 11 & 10 & 9 & 8 & 7 & 6 & 5 & 4 & 3 & 2 & 1 & Totals \\
\hline Boys & 215 & 539 & 1517 & 2692 & 2725 & 2483 & 1087 & 1240 & 989 & 820 & 788 & 1407 & 17,502 \\
\hline Girls & 251 & 554 & 1261 & 2101 & 2202 & 2604 & 704 & 800 & 706 & 617 & 701 & 1145 & 13,650 \\
\hline $\begin{array}{l}\text { Total by } \\
\text { Grades }\end{array}$ & 466 & 1093 & 2778 & 4793 & 4931 & 6087 & 1791 & 2040 & 1695 & 1437 & 1489 & 2552 & 31,152 \\
\hline
\end{tabular}

DISTRIBUTION OF ABSENCES IN 5 DAY PERIODS BY GRADES

\begin{tabular}{l|r|r|r|r|r|r|r|r|r|r|r|r|r}
\hline Days absent & 12 & 11 & 10 & 9 & 8 & 7 & 6 & 5 & 4 & 3 & 2 & 1 & Totals \\
\hline No absence & 27 & 38 & 48 & 92 & 88 & 99 & 38 & 34 & 39 & 28 & 38 & 65 & 634 \\
\hline $1-5$ & 177 & 343 & 798 & 1557 & 1684 & 2189 & 629 & 718 & 631 & 561 & 504 & 746 & 10,538 \\
\hline $6-10$ & 109 & 245 & 711 & 1283 & 1352 & 1776 & 455 & 521 & 428 & 376 & 376 & 554 & 8,186 \\
\hline $11-15$ & 68 & 193 & 481 & 760 & 762 & 827 & 270 & 330 & 255 & 204 & 217 & 393 & 4,760 \\
\hline $16-20$ & 38 & 139 & 308 & 447 & 396 & 436 & 154 & 178 & 134 & 98 & 124 & 268 & 2,720 \\
\hline $21-25$ & 17 & 66 & 169 & 254 & 241 & 298 & 88 & 123 & 89 & 65 & 103 & 185 & 1,698 \\
\hline $26-30$ & 15 & 34 & 120 & 147 & 141 & 182 & 65 & 51 & 45 & 40 & 47 & 113 & 1,000 \\
\hline $31-35$ & 8 & 16 & 64 & 99 & 108 & 124 & 39 & 28 & 32 & 27 & 31 & 83 & 659 \\
\hline $36-40$ & 5 & 9 & 39 & 67 & 61 & 57 & 13 & 26 & 13 & 17 & 22 & 52 & 381 \\
\hline Over 40 & 2 & 9 & 40 & 87 & 98 & 99 & 40 & 30 & 29 & 21 & 28 & 93 & 576 \\
\hline Totols & 466 & 1093 & 2778 & 4793 & 4931 & 6087 & 1791 & 2040 & 1695 & 1437 & 1489 & 2552 & 31,152 \\
\hline
\end{tabular}

TTMES CALLED UPON

\begin{tabular}{c|c|c|c|c|c|c|c} 
Calls & 1 & 2 & 3 & 4 & 5 & 6 or more & Totals \\
\hline Casès & 11,204 & 7,152 & 4,759 & 2,801 & 1,770 & 3,466 & 31,152
\end{tabular}


Percentage of absence in 5 day groups

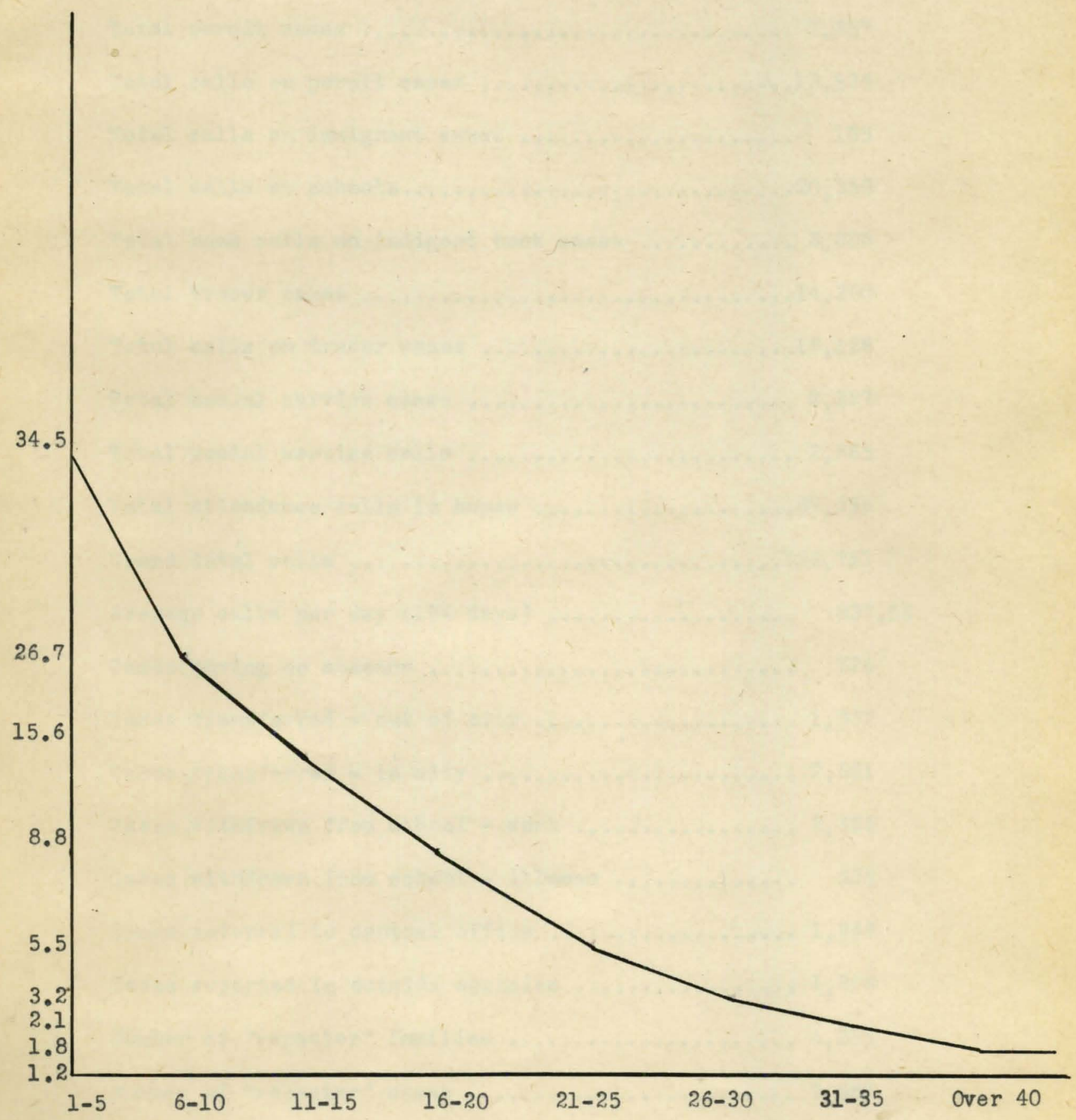




\section{ANNUAL ATTENDANCE REPORT}

\section{$1927-28$}

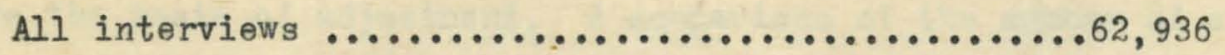

Total calls on special school cases ............ 1,592

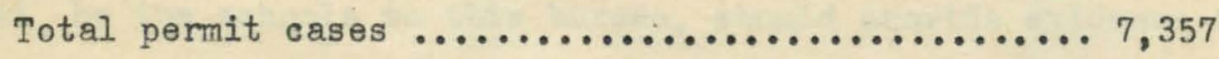

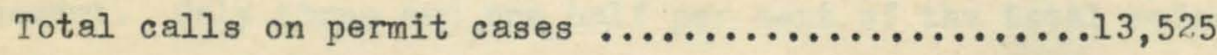

Total calls on immigrant cases ................ 155

Total calls at schools.....................20,358

Total home calls on indigent book cases ........2,808

Total tracer cases .........................14,200

Total calls on tracer cases $\ldots \ldots \ldots \ldots \ldots \ldots \ldots \ldots \ldots, 126$

Total social service cases $\ldots \ldots \ldots \ldots \ldots \ldots \ldots \ldots \ldots, 327$

Total social service calls $\ldots \ldots \ldots \ldots \ldots \ldots \ldots \ldots \ldots, 865$

Total attendance calls in homes $\ldots \ldots \ldots \ldots \ldots \ldots .8,356$

Grand total calls ......................

Average calls per day (184 days) $\ldots \ldots \ldots \ldots \ldots \ldots \ldots$...... 837.56

Cases having no absence ....................... 724

Cases transferred - out of city $\ldots \ldots \ldots \ldots \ldots \ldots \ldots 1,332$

Cases transferred - in city $\ldots \ldots \ldots \ldots \ldots \ldots \ldots \ldots, 861$

Cases withdrawn from school - work ............ 2,356

Cases withdrawn from school - illness ........... 524

Cases referred to central of fice .............. 1,969

Cases reported to outside agencies ............ 1,808

Number of "repeater" families .............. 4,255

Number of "repeater" cases .................. 9,687 
One sometimes meets people who think that the function of any organization dealing with children is primitive; that punishments more or less severe are the basis of adjustment. A comparison of the number of cases taken before the juvenile court and the dispositions, with the total number referred by the schools to this bureau, should provide evidence for disillusionment. Only three and one half per cent of the total referred or six-tenths of one per cent of the total school enrollment were brought before this agency during the school year. Many of this number were filed against because parents failed to appreciate a request to come to this bureau when they received the official notice.

The dispositions indicate a tendency of the court to avoid primitive measures as much as possible. Sixteen parents were fined or detained and one hundred seventeen boys and girls sent to the industrial schools, in an effort to adjust them to the requirements of society. Practically all the remainder returned to the custody of the school system, or placed under the care of agencies especially adapted to assist in solving the problem.

In passing, j.t may also be stated that the most cordial relations exist between the court and the schools, partially due at least to the well trained worker who does all the court work for the department and also the knowledge that the department has exhausted the possibilities of the school system in attempted adjustments before filing charges against the parent or child.

A summary of the work of the bureau through the juvenile court is given on the next page. This shows the total cases handled and the disposition made of each case. 


\section{JUVENILE COURT RFPORT}

\section{Report of Filings and Dispositions}

\section{Cases Referred:}

$\begin{array}{cc}\text { Unofficial }- & \text { Boys } \\ \text { Girls } & \frac{149}{435} \\ \text { Total } & 435\end{array}$

$\begin{array}{cr}\text { Official - Boys } & 517 \\ \text { Girls } & \frac{155}{672} \\ \text { Total } & 672\end{array}$

Dispositions:

\section{Unofficial}

Boys Girls

Thomas A. Edison School .......... 116

Work permits issued .............. 46

Paroled to attendance department ... 35

Ran away from home .............. 29

Detention home .................. 25

Left city .................... 9

Doctor's certificate ............. 5

Hospital ..................... 3

Child guide clinic ............. 3

Transferred .................. 3

Warrant issued ................. 2

Humane society .................. I

Parent fined .................. I

Parent jailed ................... I

Women's Protective Association ..... I

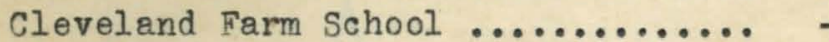

Warrensville Girl's Farm ............ -

Boy's Industrial School ............ -

Girl's Industrial school ........... -

Paroled to Probation Officer ....... -

Probated ........................ -

Fresh Air Camp ................... -

Farmdale ...................... -

Children's Bureau ................ -

Feeble Minded Institute ............. -

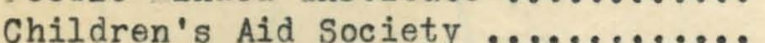

Referred to Associated Charities ...

Sight Saving Department ...........

City Hospital - Psychopathic .......

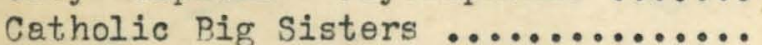

Sunbeam School - crippled ..........

Summer school ....................

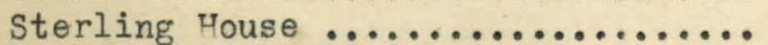

Bureau of Juvenile Research ........ -

Convent of Good Shepherd.

--
23
82
3
9
5
6
1
1
7
-
-
-
-
-
-
-
-
-
-
-
-
-
-
-
-
1
-
-
1
1
3
2
-
-

\section{officiel Boys Girls}

$203 \quad--$

$46 \quad 19$

$42 \quad 40$

-- 1

$27 \quad 11$

154

13

94

32

1 1

- -

85

31

73

45

$49 \quad-$

$-2$

$59 \quad-$

$28 \quad 25$

31

1 -

1 -

31

11

31

1 -

-

-

- 1

1 -

- $\quad$

-

23 


\section{Relation of Boys To Girls Desiring To Leave School}

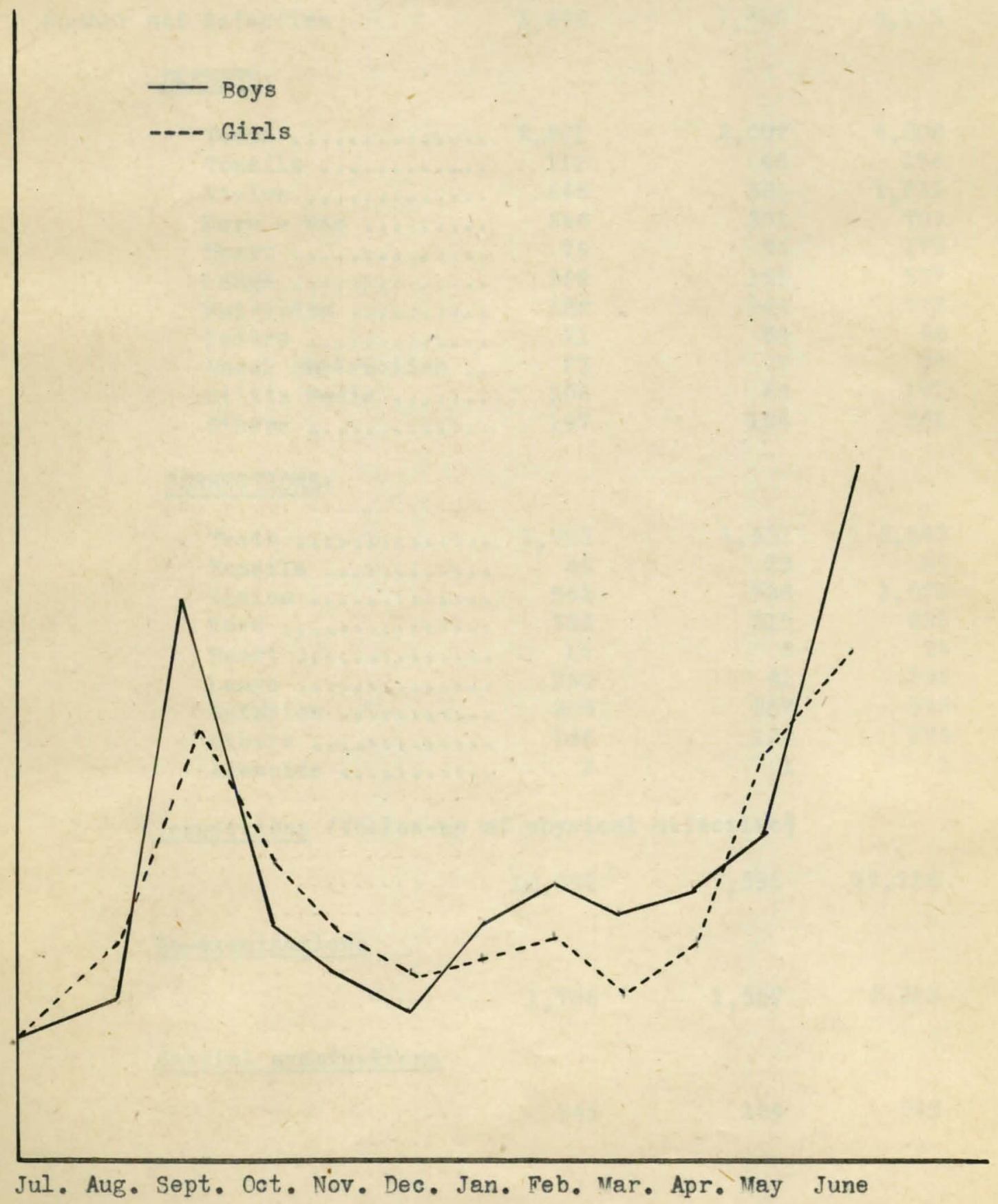




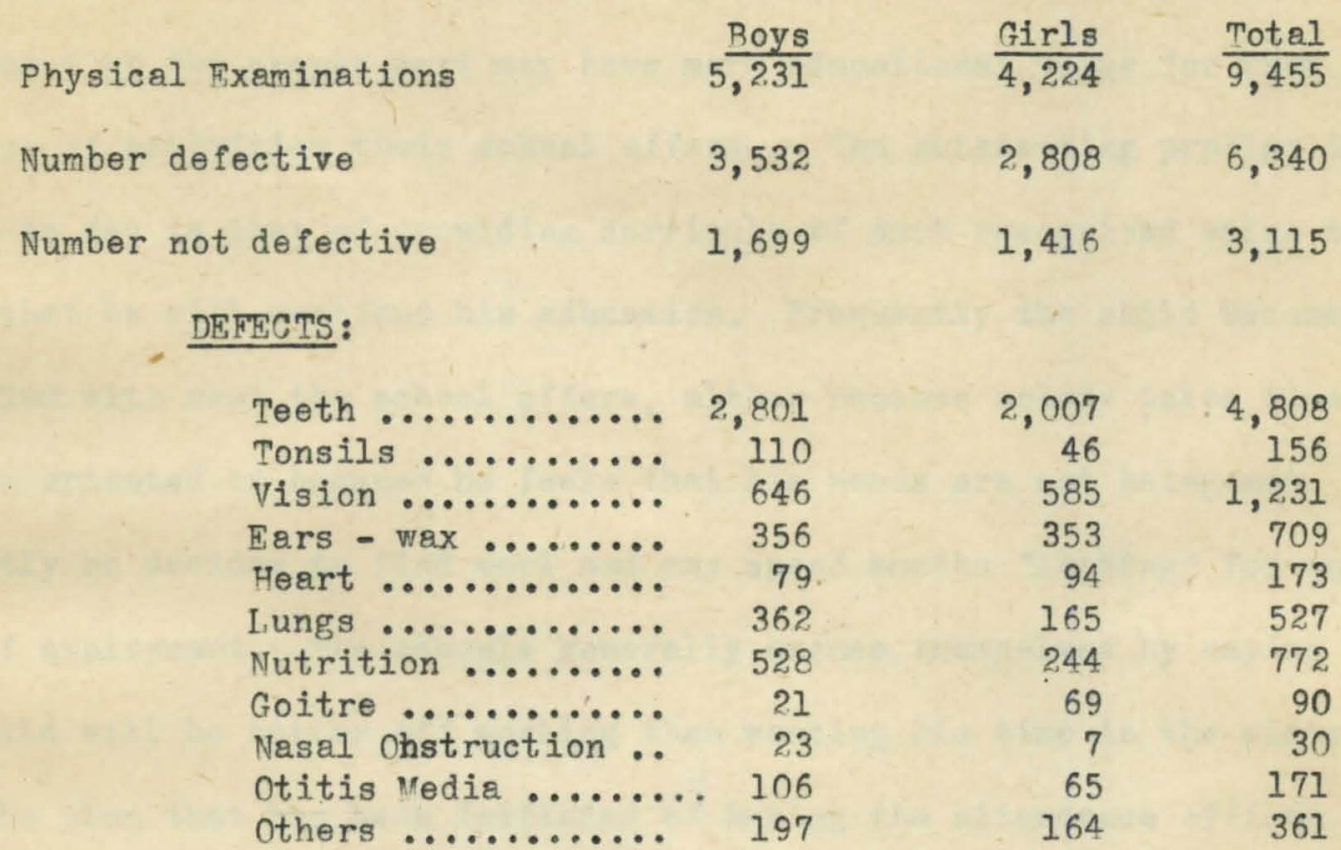

\section{CORRECTIONS:}

$\begin{array}{lrrr}\text { Teeth } \ldots \ldots \ldots \ldots \ldots \ldots & 1,993 & 1,531 & 3,542 \\ \text { Tonsils } \ldots \ldots \ldots \ldots \ldots & 46 & 23 & 69 \\ \text { Vision } \ldots \ldots \ldots \ldots \ldots & 542 & 536 & 1,078 \\ \text { Ears } \ldots \ldots \ldots \ldots \ldots \ldots & 338 & 315 & 653 \\ \text { Heart } \ldots \ldots \ldots \ldots \ldots \ldots & 16 & 8 & 24 \\ \text { Lungs } \ldots \ldots \ldots \ldots \ldots \ldots & 250 & 81 & 331 \\ \text { Nutrition } \ldots \ldots \ldots \ldots \ldots & 206 & 362 & 568 \\ \text { Others } \ldots \ldots \ldots \ldots \ldots & 146 & 128 & 274 \\ \text { Adenoids } \ldots \ldots \ldots \ldots \ldots & 2 & 1 & 3\end{array}$

Inspections (follow-up of physical defective)

$$
10,093 \quad 7,635 \quad 17,728
$$

$\underline{\text { Re-examinations }}$

$$
1,726 \quad 1,587 \quad 2,313
$$

Special examinations 
Many children as they approach the age of sixteen become imbued with the idea that industry is greatly in need of their services. In a number of cases employment of the proper sort may have more educational value for them than the type of activities their school offers.. The outstanding problem in education to day is that of providing curricula of such recognized value to the child that he will continue his education. Frequently the child becomes dissatisfied with what the school offers, either because nobody takes time to get him oriented or because he feels that his needs are not being met. Consequently he decides to find work and may spend months "looking" for any kind of employment. The schools generally excuse themselves by saying that the child will be better off working than wasting his time in the class room. The plan that has been initiated of having the attendance officer at the school issue contract cards to children who leave school to work was found to be quite satisfactory. The most important thing in its favor is the close follow-up it provides.

The number of children who reach sixteen years of age before completing seventh grade is growing less each year. Among other evile, this one must be corrected and it is with this problem that attendance departments are having their greatest struggle.

The foregoing review of previous studies of unexcused absences has been made to determine whether some cause more fundamental than poverty, perental neglect and indifference, mental and physical defects and social maladjustment, is here operative. The present study has been undertaken to throw light upon this significant question. 
It is evident from the reports of the various cities that truancy is a complex problem which may be due to an impulse of youth, the spirit of adventure or the product, in some instances, of heritage. Often it is due to mental retardation of the backward pupil, "the over grown boy whose body has out grown the lower grades, but whose stunted mind keeps him captive, there to listen to the taunts of the teacher of the little fellows who pass him in promotional examinations".

The causes of truancy are numerous as well as varied. They may be some fancied grievance with the teacher or an unsympathetic teacher; the evil influence of bad companionship; the environment of poverty and unsanitary housing; lack of cooperation of negligent parents and school authorities; malnutrition and the physical rebellion of an underfed child; visual defects; adenoids; classification of pupils into other than homogenoous groups; educational, social, mental, or personality handicaps or A varying combinations of these causes.

An investigation into the causes of irregular attendance and infractions of the code of social conduct almost invariably lead to the elimination of the difficulty and the prevention of further problems through a better understanding between the home and the school.

Most of the truants come from the third, fourth and fifth grades. However the ages at which the majority of children get the truancy habit are from eleven to thirteen.

Every child is entitled to those things in life that are mentally stimulating, physically wholesome and socially satisfying. "It has been proven by investigation that the children that have the factors condu cive 
to the highest development enjoy thrity-three per cent better chances in school and life than do those children who come from indifferent and neglected homes". Heredity seems most logically to be the greatest determining factor in the child's life. The child displays, to a marked degree, certain inherent tendencies and characteristics which may or may not be corrected as time goes on. Fnvironment may play a prominent part here but the physical scar upon the life of the parent may mar the life of the child irreparably.

Therefore, if an accurate conclusion is to be obtained, it must be done by investigating the personal and family history of the case, the hereditary factors, birth conditions, record of diseases, school history, physical and mental development, social adjustment and present physical and mental condition.

"Heredity (inheritance) is of foremost importance but the environment provided for the years in which the child's mind is susceptible and his character plastic is also of importance". "any parents are ignorant of the laws of healthy growth, intellectual development, the acquisition of moral power and of spiritual insight so that as a result the child is a problem of maladjustment. Consequently irregular attendance is merely a symptom of maladjustment which causes an unhealthy condition in the school.

In a public school system which serves all the children of a community, most children need some adjustment and a program of prevention must effect not only the upper and lower ten per cent but the eighty per cent whom neither the teacher nor the principal see until after the problem has developed.

"The benefits of compulsory education are too clear to admit of argument. Through enlightened public opinion and well-principled moral sentiment it is hoped that there will be a security in democracy beyond the law and above the 
law. Likewise, through the improvement of our educational ideals and standards and their universal application, we shall approach the better democracy which we cherish and to which we are dedicated". 


\section{BIBLIOGRAPHY}

1. Laws Relating to Compulsory Education: Bureau of Education, Bulletin Number 20, 1928

2. The Purpose and Scope of Visiting Teacher Work: Howard W. Nudd

3. Courts in the United States Hearing Children's Cases: U. S. Department of Labor, Bulletin Number 65, 1920

4. Juvenile Courts at Work: U.-S. Department of Labor, Bulletin Number 141, 1925

5. Proceedings of the National League of Compulsory Education Officials: $1923,1924,1926$

6. Mental Health of the School Child: Wallin

7. Hygiene of the School Child: Terman

8. Annual Report of the Superintendent of Instruction: St Louis, Mo., $1920-21,1926-28$

9. Truancy and Non-Attendance in the Chicago Schools: Abbot and Breckenridge

10. Annual Report of Compulsory Education: Philadelphia, 1925,1928

11. Department of Attendance, Reference and Procedure: Detroit, 1926

12. Annual Report of the Superintendent: Boston, Document Number 12, 1927

13. Studies in School Attendance: Blanch Merry, Bulletin Number 91, Indianapolis, 1927

14. Child Accounting in Indiana: Blanch Merry, Bulletin Number 85, 1926

15. Annual Report of the School Board: Springfield, Mass., 1924

16. Division of Attendance: Cleveland, Ohio

17. Annual Report of the Superintendent: Chicago, Illinois, 1927

18. Department of Attendance: Portland, Oregon, 1927-28

19. Annual Report of the Attendance Department: Rochester, N. Y., 1926-27 
20. Superintendent's Report: Pittsburg, Penn., 1926

21. Division of Attendance: Austin N. Miller, Harrisburg, Penn., 1928

22. Commonwealth Fund Program for the Prevention of Delinquency: New York, 1926 